\title{
UN SOLITARIO EN LA CORTE LAS PARADOXAS RACIONALES, DE ANTONIO LÓPEZ DE VEGA
}

El ms. 7903 de la Biblioteca Nacional de Madrid que contiene las Paradoxas racionales, escritas por Antonio López de Vega, permaneció inédito hasta que, en 1935, fue publicado por Erasmo Buceta ${ }^{1}$. Ese manuscrito -no así otro del mismo texto, también perteneciente a la Biblioteca Nacional de Madrid- tiene las licencias para su publicación, que permiten fecharlo. La primera solicitud de aprobación es del 18 de noviembre de 1654; el último informe recomendando se dé licencia de impresión, escrito por Agustín de Castro, padre jesuíta, data del 21 de febrero de 16552. De todos modos, el libro no fue impreso. Acaso haya incidido en ello la muerte del autor, cuya fecha se desconoce (los preliminares del manuscrito son, de hecho, el testimonio más

1 Antonio López de Vega, Paradoxas racionales, escritas en forma de diálogos del género narrativo la primera, del activo las demás, entre un cortesano i un filósofo, editadas con una introducción de Erasmo Buceta, Junta para Ampliación de Estudios-Centro de Estudios Históricos, Madrid, 1935; el volumen es el Anejo 21 de la $R F E$ (citaré el texto por esta edición, indicando los números de páginas entre paréntesis). El segundo manuscrito que menciono a continuación es el que lleva la signatura 17.897 de la BNM; lleva el título de $R a$ zionales paradojas y está escrito con letra del siglo xvirr, según describe Buceta (p. xxiii).

${ }^{2}$ No era la primera vez que el padre Agustín de Castro, miembro además del Colegio Imperial de Madrid, aprobaba un texto de Antonio López de Vega. El mismo Agustín de Castro firmó en 1639 la aprobación de Heráclito i Demócrito de nuestro siglo (MARIE-LAURE ACQUIER, "Los tratados en prosa de Antonio López de Vega: aproximación al discurso político en el siglo xvir", Cuadernos de Historia Moderna, 24, 2000, p. 92). El manuscrito de las Paradoxas racionales tiene como colofón la fecha 12 de noviembre de 1655 , a la que podría corresponder el fin de la revisión que dejó las anotaciones al margen que en él aparecen. 
tardío para inferir el año de la muerte de Antonio López de Vega) aunque, según afirma Paulino Garagorri, los motivos de que las Paradoxas racionales no hayan sido publicadas son otros: "sus atrevimientos de juicio explican que quedasen inéditas" 3 .

Es sobre todo este crítico quien ha insistido en la "modernidad" de la obra de López de Vega. Ubica esta modernidad, sobre todo, en el elogio de la razón como fundamento necesario y suficiente para el conocimiento -y Garagorri recuerda el hecho de que el autor de las Paradoxas racionales fue coetáneo de Descartes. Probablemente, debido a la sorpresa que produce encontrar en un texto de fines del Barroco español este tipo de posiciones, en general la crítica ha subrayado ese aspecto de los tratados de López de Vega tanto como ningún otro. Así, la obra de López de Vega ha sido leída, fundamentalmente, atendiendo a su planteo filosófico o, si se quiere, epistemológico. Sin embargo, en los tratados morales que forman parte de su obra también puede reconocerse la presencia de la política de la primera mitad del siglo xvn español y, por lo tanto, ponen en escena la relación estrecha que conecta moralidad y política. Más aún, bajo la llamada a la razón y al desengaño, y bajo la propuesta de una ética estoica, creo que es posible leer el testimonio de la aparición de una forma de sociabilidad propia de la modernidad y de una determinada relación entre los ámbitos de lo privado y lo público. Así, la modernidad del texto no radicaría tanto en su llamada a la razón, o en la secularización de su ética, sino más bien en la defensa de una esfera privada de la conciencia que se constituirá en el lugar específico de enunciación de la opinión pública.

Es en este punto en donde el texto se articula con la política. Puesto que la independencia del ámbito privado conlleva un reconocimiento de lo que llamamos hoy día "opinión pública", las intervenciones políticas de los personajes son las opiniones del "mediano". Y esa "medianía" puede rastrearse no sólo en la ética propuesta sino también en el implícito reconocimiento de la división de esferas, cuando el letrado defiende sus "fueros" y discute con las "armas". Por lo demás, puesto que el editor ha conservado las correcciones marginales del manuscrito ${ }^{4}$, el

3 "Antonio López de Vega, un filósofo de capa y espada", $L T, 1967$, núm. 58, p. 117. GaRAGORRI atribuye explícitamente a la Inquisición el hecho de que no se hayan impreso las Paradoxas racionales; dice que López de Vega las "dejó inéditas, probablemente a su pesar y por culpa del Santo Oficio" (ibid., p. 108).

${ }^{4}$ En su ed. cit., Buceta dice que "respecto de las correcciones que se hallan en el manuscrito, las acepto siempre, por parecerme muy atinadas, 
texto ofrece una excelente oportunidad de reflexionar sobre la presencia en la escritura de un contexto cultural altamente represivo, institucionalizado en la censura. Este hecho importa en tanto nos encontramos frente a un texto con un alto grado de intervención política. Un aspecto que, como ya he señalado, fue frecuentemente soslayado en los trabajos críticos sobre la obra de López de Vega, en la que sobre todo se ha leído una determinada filosofía.

\section{LA trayectoria de ANTonio López de Vega}

Si bien son escasos los testimonios que permiten conocer la biografía del autor, se sabe que Antonio López de Vega nació en Lisboa hacia $1586^{5}$. La incorporación en 1580 de Portugal en la monarquía española facilitó la llegada de López de Vega a la corte de Madrid ${ }^{6}$. Buceta cita la breve biografia que aparece en la Bibliotheca Lusitana de Barbosa Machado:

probablemente obra del mismo autor. Las tachaduras, cuando tienen alguna importancia, las indico; si es posible leer bajo lo borrado -y las juzgo de interés-van copiadas en nota al pie de página" (p. xli); y agrega: "sospecho que la eliminación de ciertas frases -en una ocasión una página entera- ha debido de ser originada por el recelo de la Inquisición" (p. xli).

${ }^{5}$ Este dato, que tomo tanto de Buceta (p. xiv) como de AcQuier ("Los tratados en prosa", p. 85), aparece fundamentalmente en dos textos: Nicolís ANTONIO, Bibliotheca Hispana Nova sive hispanorum scriptorum qui ab anno MD ad MDCLXXXIV floruere notitia, Matrini, apud viduam et heredes Joachimi de Ibarra typographi Regii, MDCIXXXVIII, t. 1, p. 141 y Diogo Barbosa MachaDo, Bibliotheca Lusitana Historica, Critica e Cronologica. Na qual se comprehende a noticia dos Authores Portuguezes, e das Obras, que compuzeraõ desde o tempo da promulgaçaõ da Ley de Graça até o tempo presente, Officina de Ignacio Rodrigues, Lisboa, 1741-1759, t. 1, pp. 310-311.

${ }^{6}$ Algunos críticos han discutido la posible ascendencia judía de López de Vega. Uno de los datos para tal hipótesis es un poema de Villamediana posiblemente referido a él: "Académico sea la Vega / En vuestra judaiçante compañía / Y no ya Vega del Ave-María / Sino del torpe tribu que la niega. / Del tal Mecenas de congragada / Judaica plebe, ya Toledo espera / Nuevas llamas, y Cristo otra lanzada? / Macha [sic: ¿mucha?] luz me promete, y poca cera / Gente que por confesa confesada / Por luminaria nos dará su hoguera" (ACQuier, "Los tratados en prosa”, p. 89). Véase Henry Méchoulan "La notion de vie chez trois présumés 'conversos': Las Casas, López Bravo et López de Vega", en Homenaje a Julio Caro Baroja, eds. A. Carreira et al, CIS, Madrid, 1978, pp. 771-785. 
Antonio Lopes da Veiga, natural de Lisboa, e sobrino de D. Fr. Diogo Lopes de Andrade, Eremita de S. Agostinho, e Bispo de Otranto, que conhecendo o grande talento que descubria na adolescencia para as letras humanas e filosofia o levou na sua companhia para Madrid, onde brilhasse o seu engenho entre os varoens mais eruditos. Tanto que chegou a esta corte se fez estimado das principaes pessoas de ambas a jerarchias, pois nelle veneravăo felismente unidas as ciencias da poesia, historia antigua e moderna, philosophia e matemãtica, com os dotes de hum genio afable, vida innocente e animo modesto. Sempre era consultado pelos sabios en materias eruditas, observando a sua decisảo como de orảculo. Não houve certame litterario em que não levasse a palma a todos os competidores. Foy secretario do condestable de Castella, que para seu uso lhe fez patente a sua grande Bibliotheca. Vivia en Madrid no anno 1656, quando ja contava setenta de idade, até que na mesma corte dechou o circulo da vida ${ }^{7}$.

De su carrera en la corte, Marie-Laure Acquier dice que "lo que llama la atención en su itinerario, es el cambio incesante de protectores a lo largo de su carrera literaria y cortesana, lo que podría significar que estuvo buscando durante toda su vida una consagración social que no llegó a alcanzar con ninguno de sus mecenas". Las obras publicadas por López de Vega permiten inferir un alto grado de participación en la vida cortesana de la época. Su primera aparición pública es en 1614, en un concurso poético organizado para las fiestas de beatificación de Teresa de Jesús en el convento de las carmelitas descalzas de San Hermenegildo de Madrid y en el libro que recoge las participaciones del certamen, de $1615^{9}$. A partir de entonces, según Buceta,

7 Bibliotheca Lusitana, t. 1, pp. 310-311, apud Buceta (pp. xiv-xv), que también reproduce el texto de Nicolás Antonio: "Antonius Lopez de Vega, Lusitanus, majorem vitæ partem Matriti in cura egit, carus cunctis, \& in pretio habitus ob studiorum philosophia ac poetices, necnon \& hisoriæe antiquæ \& nova: excellentiam, simul \& modestiam. Elucubravit propia Castellanorum lingua, quam egrerie calluit..." (Bibliotheca Hispana Nova, t. 1, p. 141, apud Buceta, p. ix).

8 ACQUiER, "Los tratados en prosa", p. 94.

${ }^{9}$ LÓPEZ DE VEGA, "Ardiente luz, que a tu divina esfera...", canción en fray Diego de San Joseph, Compendio de las solenes fiestas que en toda España se hicieron en la Beatificación de N. B. M. Teresa de Jesús, fundadora de la reformación de Descalzos y Descalzas de N. S. del Carmen, en prosa y en verso. Dirigido al Ilmo. Señor Cardenal Millino, vicario de nuestro santíssimo padre y sr Paulo Quinto y protector de toda la orden. Por Fray Diego de San Joseph, religioso de la misma reforma, Secretario de N. P General, por la viuda de Alonso Martín, Madrid, 1615 (AcquiEr, "Los 
"podemos descubrir, aun hoy, pruebas de una vida de relación bastante activa en las esferas literarias de la época" (p. xvi). Cuando en 1652 López de Vega reedita el primero de sus tratados en prosa, El perfeto señor, recopilando en el volumen varios de los poemas compuestos hasta ese momento, explica en el prólogo por qué escribió los versos añadidos:

Para servir á la pasión agena... ya serán de los Amigos, ya de algún Superior, á quien el Respeto, ó la Conveniencia, no permitan el escusarse. El Volumen, al fin se haze con esto más vario, se haze más general, i también más corpulento; Estratagemas todas, i Razones de Estado de qualquiera Escritor, que no quiera desvanecerse, en hazer punto del Menosprecio del común Agrado ${ }^{10}$.

La labor de López de Vega como poeta, por lo tanto, está íntimamente ligada con la vida política de la corte de la época. A menudo, esta labor cobra el carácter de apología de los poderosos:

Toma parte en la estrafalaria exudación poética -genuina exaltación faraónica, símbolo patente de la efectiva decadencia del espíritu del país, que trueca la lealtad por la inepta adoración del soberano- con motivo de haber dado muerte Felipe IV a un toro de un arcabuzazo en la lucha de fieras celebrada en los jardines de Palacio. Compone sonetos a la muerte de hermanos en poesía -Baltasar Elisio de Medinilla y Luis Vélez de Guevara- o a la de testas coronadas -las reinas D. ${ }^{\mathrm{a}}$ Margarita de Austria, D. ${ }^{\mathrm{a}}$ Isabel de Borbón, al túmulo de Felipe III, "el Casto, el Pío, i el Grande".

Asimismo interviene en certámenes celebrados para honrar la corte celestial -a Santa Teresa y a Santa Isabel, a San Isidro y a San Ignacio de Loyola, a San Francisco Javier, etc.-; o para festejar, con petulancia, glorias urbanas en que lo terreno y lo divino -la veneración al césar y el interés hagiográfico- se juntan en

tratados en prosa", p. 89). La autora dice que el libro fue "uno de los bestsellers del año".

${ }^{10}$ Apud AcQuier, "Los tratados en prosa", p. 88. Nótese la expresión "razones de estado del escritor", tópico de la época; Acquier, para mostrar cómo la "estrategia discursiva de López de Vega recoge unos tipos argumentales ya forjados en su época, y admitidos por las autoridades" dice que "la generalización de la expresión «razón de estado» en los contextos más diversos (se hablaba de "razón de estado" del escritor, expresión empleada por el propio López de Vega) muestra que ésta se extiende más allá del ámbito político, en detrimento de su precisión semántica" (ibid., p. 101). 
mezcla monstruosa y casi sacrílega... Adereza, por fin, otras composiciones, igualmente de circunstancias, las cuales se basan en cimiento más laico, si bien de escasísimo calibre poético. Versos de concurso, temas obligados; poesías de compromiso, manufacturadas según dechado ${ }^{11}$.

En resumen, López de Vega se muestra así como un hombre que intenta hacerse un lugar en la corte madrileña. Lo que parece caracterizar su obra es la escisión entre una lírica de circunstancias, que dedica casi completamente a sus "estrategias" de ascenso social, y una prosa de reflexión moral en la que, atendiendo al modelo de comportamiento propuesto, se cuestionan esos procedimientos ${ }^{12}$.

Además de las Paradoxas racionales, su obra se compone de un libro de poesía y dos tratados en prosa, todas obras que, desde la muerte de López de Vega, nunca fueron reeditadas. Lírica poesía (Bernardino de Guzmán, Madrid, 1620), es la recopilación de sus poemas, escritos en varios idiomas. El volumen fue publicado al tiempo que conseguía la protección del hijo del Duque de Alba, Fernando de Toledo, Duque de Huéscar, heredero de la familia, es decir que López de Vega quedaba bajo la protección de la familia de los virreyes de Nápoles, mecenas de Boscán y de Lope de Vega. El primero de sus tratados en prosa es El perfeto señor Sueño político (Viuda de Alonso Martín, Madrid, $\left.1626^{13}\right)$. En la portada, el autor aparece como "Secretario del excellentíssimo señor Don Bernardino Fernández de Velasco i Tovar, condestable de Castilla i León"14. Este mismo libro será

${ }^{11}$ Buceta, pp. xvii-xix. La mayor parte de estas composiciones se encuentran recopiladas por el autor en la segunda edición de El perfeto Señor.

12 Conflicto y fenómeno coherente con la "dependencia propia de la ocupación del escritor en el antiguo régimen", condicionada por el clientelismo y el mecenazgo (AcQuier, "Los tratados en prosa", p. 87).

${ }^{13}$ El libro, por lo tanto, es publicado "durante el período de suspensión de las licencias de impresión de las comedias y novelas que duró de 1625 a 1634" (ACQuiER, "Los tratados en prosa", p. 103). La autora, que atribuye también a esta circunstancia el hecho de que López de Vega, que había sido poeta, llegara a escribir libros didácticos, señala que "nunca se priva en sus obras del pretexto narrativo, manifestando así cierta inclinación por la materia ficcional" (ibid., p. 104).

${ }^{14}$ ACQuiER, "Los tratados en prosa", p. 91. La autora señala que "no se sabe cuándo entró López de Vega al servicio de Bernardino, pero sí se sabe que quedó en el cargo por lo menos dos años" gracias a una carta de Miguel Moreno, dirigida a "Antonio López de Vega, secretario del Condestable de Castilla", que aparece en la edición de 1628 de su novela El cuerdo amante. 
ampliado en una reedición posterior, El perfeto señor Sueño politico. Con otros varios discursos, $i$ últimas poesias varias (Imprenta Real, Madrid, 1652) y hay una tercera edición exactamente igual a ésta, excepto la portada, de 1653. El segundo tratado en prosa es Heráclito i Demócrito de nuestro siglo. Deserívese su legítimo Filósofo. Diálogos morales sobre tres materias, la Nobleza, la Riqueza y las Letras, publicado por Diego Díaz de la Carrera, a costa del librero Alonso Pérez de Montalbán, protector de Félix Lope de Vega, en 1641. Salvo estos datos que surgen de los preliminares de las obras, el rastro del autor se pierde, sin que se sepa cuándo murió ni en qué circunstancias; la única certeza es que, con la separación de Portugal de la corona de Castilla, López de Vega quedó en la "situación de exiliado efectivo después de 1640"15.

Como se dijo, exceptuando las Paradoxas racionales-qne durante la vida del autor permaneció inédita-, las obras de López de Vega nunca fueron reeditadas después de su muerte ${ }^{16}$. Esta falta de reediciones es correlativa de una similar suerte con la crítica. Señala Buceta que "al llegar la decimoctava centuria ya nadie recuerda sus versos. Su pensamiento, en cambio, tal como aparece expresado en los ensayos, coincidía en bastante amplia proporción con el espíritu del siglo" (pp. ix-x). Pero este conocimiento se irá perdiendo poco a poco; así, "en la actual centuria su nombre parece apagarse aún más” (p. xii). Buceta, en el prólogo a su edición, enumera los contados trabajos críticos que tratan sobre los libros escritos por López de Vega ${ }^{17}$.

Según la misma autora, el cargo de secretario de Bernardino Fernández de Velasco es un empleo que consiguió gracias a los contactos cortesanos de su tío (ibid., p. 90).

${ }^{15}$ ACQuier, "Los tratados en prosa", p. 105.

${ }^{16}$ Existe solamente la reproducción de un fragmento del "Diálogo de los poetas" del Heráclito i Demócrito en la antología de Federico Sánchez Escribano y Alberto Porqueras Mayo, Preceptiva dramática española del Renacimiento y el Barroco ( $2^{\mathrm{a}}$ ed., Gredos, Madrid; 1972), que AlberTo PorQueras Mayo volvió a publicar en su libro La teoría poética en el Manierismo y Barroco españoles (Puvill Libros, Barcelona, 1986).

${ }^{17}$ Además de los que Buceta revela, sólo he podido encontrar un artículo anterior a 1935 en que se menciona lateralmente al autor de las Paradoxas. Se trata del trabajo de J. P. Wickersham CRAWFord, "A letter from Medinilla to Lope de Vega", MLN, 23 (1908), 234-238; la referencia a Antonio López de Vega aparece en la p. 235; el autor cita dos sonetos del libro Lírica poesía para probar, a partir del privilegio de impresión, fechado el 19 de marzo de $1619-y$ accesoriamente a partir de la tasa, del 23 de noviembre de 1620-, la fecha de la muerte de Baltasar Elisio de Medinilla, tema sobre el que tratan los poemas. 
Desde la edición en 1935 de las Paradoxas racionales, de modo sorprendente, son igualmente escasos los artículos dedicados a su obra ${ }^{18}$ o que, en alguna medida, la consideran ${ }^{19}$.

\section{LAS PARADOXAS RACIONALES Y EL NEOESTOICISMO}

Tal como señala el autor en el prólogo, sin duda las "paradojas" no eran una novedad: "Muy grandes varones, antes i después del gran Cicerón, han echado por paradoxas" (p. 7). A partir de esta explícita referencia a la Paradoxa Ad M. Brutum, en la introducción de su edición, Buceta traza un recorrido histórico de esta suerte de subgénero. Las más cercanas a las de López de Vega son las

18 Conozco apenas una docena de trabajos sobre su obra: el artículo de Paulino Garagorri ya citado, la tesis de A. R. Butz (El filósofo cortesano. Das moralistische Werk des Antonio López de Vega, Freiburg i. Br., 1975), los artículos de Henry Méchoulan (el citado en nota 6 y "Fadrique Funió Ceriol zet Antonio López de Vega, deux hétérodoxes méconnus", Penseurs hétérodoxes du monde hispanique, Université de Toulouse-Le Mirail, Toulouse, 1974, pp. 115-132), Guillermo Carnero ("Las ideas literarias de Antonio Lopes da Veiga con el texto íntegro de su Diálogo de los poetas [1641]", Arquivos do Centro Cultural Português, 1983, núm. 19, 333-411), JacQueline FerReras-Savoye ("Antonio López de Vega, un representante del "diálogo humanístico» en la época barroca”, en Mélanges offerts à Maurice Molho, Éditions Hispaniques, Paris, 1988, pp. 283-294), CARLOS VAíllo ("Las teorías poéticas de Antonio López de Vega", Studia Aurea, eds. I. Arellano et al, GRISO-LEMSO, Toulouse-Pamplona, 1996, t. 1, pp. 199-206), Jeremy RobBins ("Scepticism and Stoicism in Spain: Antonio López de Vega's Heráclito y Demócrito de nuestro siglo", en Culture and society in Habsburg Spain, eds. N. Griffin et al., Tamesis, London, 2001, pp. 137-151) y, finalmente, los trabajos que le ha dedicado MARIE-Laure AcQuiER (el artículo ya citado; "El perfecto señor, sueño político de Antonio López de Vega”, BHi, 97, 1995, 631-641; "Les controverses esthétiques au Siècle d'Or. Le deuxième dialogue des lettres de Heráclito y Demócrito de nuestro siglo d'Antonio López de Vega", $M C V, 33,1997$, núm. 2; y los dos tomos titulados Antonio López de Vega [1586?-1656?]: contribution à l'étude de la littérature politique en Espagne au XvIre siècle, Université de Nanterre-Paris X, Paris, 2000). Sobre la atención quc en los últimos años se dedicó a López de Vega en Francia, véase ANTONio JIMÉnez GaRcía, "El hispanismo filosófico en la Universidad de Toulouse-Le Mirail", Anales del Seminario de Historia de la Filosofia, 2002, núm. 19, 229-240, esp. p. 234.

${ }^{19}$ Además de lás importantes referencias en los trabajos de Karl Alfred Blüher y José Antonio Maravall (quien sólo menciona las Paradoxas morales, evidentemente el único libro del autor de que dispone) a los que me referiré, hay menciones de aspectos parciales de la obra de López de Vega en menos de una decena de textos: OtIs H. GreEN, "On the attitude toward the vulgo in the Spanish Siglo de Oro", Studies in the Renaissance, 1957, núm. 4, 190-200; Monroe Z. Hafter, Gracián and perfection: Spanish moralists of the seventeenth 
Paradoxa quastiones decem, Salamanca, 1538, de Pedro Ciruelo; Paradoxum, seu de Erratis Dialecticorum libri duo, Salamanca, 1558, del lusitano Luis de Lemos; las Paradoxas y sentencias escogidas para la erudición del entendimiento y formulación de las costumbres..., impresas por Martín Montesdoca, en Sevilla, también en 1558, obra del dominicano Fr. Domingo Valtanás Mexía, dedicadas a la duquesa de Béjar, y en Amberes, en 1582, vieron la luz Paradoxa, del Brocense. Conviene, por fin, recordar las Paradoxas Christianas, del Arcediano de Cuellar y Obispo de Agrigento, D. Juan de Horozco y Covarrubias [Segovia, 1592] (pp. xxv-xxvi).

Sin embargo, si algún antecedente de las Paradoxas racionales hay que tomar en cuenta, éste es sin duda el corpus de paradojas estoicas. Karl A. Blüher sospecha que Francisco de Quevedo pudo conocerlas probablemente por la traducción latina en la edición de Epicteto preparada por H. Wolf, Epicteti stoici philosophi Encheiridion..., publicada en Colonia en $1596^{20}$. Es obvio que si esa edición pudo estar al alcance de Quevedo, lo mismo vale para López de Vega, quien, por lo demás, pudo conocer, si no directamente la traducción de Wolf, sí seguramente el texto de Quevedo que la utilizaba: Doctrina estoica (1634). Más aún, de Amberes y de 1610 son las segundas ediciones de dos libros, $J$. Lipsii Manvdvctionis ad Stoicam philosophiam libri tres y Ivsti Lipsii Physiologiae Stoicorum libri tres, en los que Justo Lipsio, según Blüher, reconstruye la filosofía estoica partiendo de Séneca y Epicteto antes que de la Stoa griega y dando una interpretación dualista al monismo estoico ${ }^{21}$. Finalmente, Karl A. Blüher dice

century, Harvard University Press, Cambridge, 1966; Charles Jago, "The "Crisis of the aristocracy» in seventeenth-century Castile", Past and Present, 84 (1979), núm. 1, 60-90; José A. FERnÁNDEZ-SANTAMARía, "Reason of state and statecraft in Spain (1595-1640)", Journal of the History of Ideas, 41 (1980), 355379; A. M. GARCía GóMEz, The legend of the laughing philosopher and its presence in Spanish literature (1500-1700), Universidad, Córdoba, 1984; JEAN-MICHEL LASPÉraS, "Manuales de educación en el Siglo de Oro", BHi, 97 (1995), 173185; Raúl Molina Recio, Antonioj. Mialdea Baena yJuan A. Gavilán SánChez, "Les manifestationes du pouvoir dans le ville: Cordoue, $\mathbf{X V I}^{\mathrm{e}}$-Xvir ${ }^{\mathrm{e}}$ siècles", La ville en Europe. 23-29 avril 1998, Université Paris 13, campus de l'IUT.de Saint Denis, pp. 15-24; y Alfonso CAS Tro SÁEnZ, "Metodología y ciencia jurídica: hacia un concepto de derecho romano", Revista de Estudios Histórico-Juridicos, 24 (2002), 11-30.

${ }^{20}$ KARL A. BlÜHer, Séneca en España. Investigaciones sobre la recepción de Séneca en España desde el siglo XII hasta el siglo XVII, Gredos, Madrid, 1983, p. 468.

21 Ibid., pp. 398-402. Las primeras ediciones de ambos libros de Justo Lipsio fueron también publicadas en Amberes, en 1604. 
que "ya antes de López de Vega, Francisco Galaz y Barahona había imitado los Paradoxa estoica en sus Paradoxas (Madrid, 1625) «en qve (principalmente) persuade a vn pretendiente á la quietud de ánimo""22. Tampoco eran nuevos los "Heráclitos y Demócritos", que habían aparecido como personajes en el tratado en prosa de 1641:

Tanto el término "Paradoxas" como la confrontación de Heráclito y Demócrito son tópicos del tiempo... conozco, en relación con los filósofos, los cuadros de Velázquez, el curioso libro de Félix de Lucio Espinosa y Malo: Vidas de los filósofos Demócrito y Heráclito (Zaragoza, 1676) ... y el "Heráclito defendido, Filósofo que lloraba siempre los sucesos del mundo" del M. R. P. Antonio de Vieyra de la Compañía de Jesús (1608-1697), editado en el volumen Varios elocuentes libros recogidos en uno (Madrid, 1722). Una muestra de carácter tópico de la pareja Heráclito-Demócrito como representantes de la filosofía es que en el auto Las cortes de la muerte (Toledo, 1557), de Miguel de Carvajal, comparecen ante la muerte como procuradores del gremio de "filósofos y letrados"...23.

Estos dos últimos tratados de López de Vega tienen en común la forma de diálogos, lo que implica un cierto proyecto didáctico. En Heráclito i Demócrito eran dos contemporáneos, apodados con los nombres de los filósofos, los que conversaban. En las Paradoxas racionales, son dos personajes sin nombre, definidos por su rol social: un Cortesano y un Filósofo. Es notorio que, en principio, "filósofo" no es un rol; sin embargo, a lo largo del texto, por oposición a los cortesanos, se convertirá en una opción ética antagónica de los criterios "irracionales" que se observan en la corte. La disciplina, pues, se transforma en una pauta de comportamiento y en una ubicación social.

Como el título indica, el texto contiene -además de un "prólogo a los censores"- seis capítulos denominados "paradoxas"24,

22 Ibid., p. 516, n. 109. La adscripción de las Paradoxas racionales al estoicismo se hace explícita cuando el cortesano, interlocutor del personaje con el que el autor se identifica, el filósofo, se refiere en una pregunta a "vuestro Séneca" (p. 68) y también en la corrección del manuscrito indicada por el editor en la p. 61, donde la palabra "estoicos" es reemplazada por la expresión "los más ajustados filósofos".

23 Garagorri, art. cit., p. 118, n. 8.

24 Téngase en cuenta la tendencia propia del Siglo de Oro español a titular las secciones de los libros evitando la denominación de "capítulos"; así, por ejemplo, en el caso paradigmático de Baltasar Gracián que en El Criticón utiliza la voz "crisis", en El héroe, "primor", etc. 
la primera ("El solitario en la corte") "escrita en forma de diálogos del género narrativo" y las demás "escritas en forma de diálogos del género activo". A lo largo de las seis secciones, el texto propone una serie de "desengaños" -todos, en mayor o menor medida, relacionados con la política de la época- por medio de los cuales el Filósofo argumenta y enseña al Cortesano una ética estoica $^{25}$ :

el ideario séneco-estoico [ejerció] influencia sobre la doctrina moral cortesana y -como se manifiesta, sobre todo, en Graciánpartiendo de ella, sobre las ideas moralistas del siglo xvn. Donde más palmario se ve esto, antes de Gracián, es en Antonio López de Vega, moralista a cuyos escritos no se ha dedicado hasta ahora la atención que merecen. La obra de López de Vega pone de manifiesto que el pensar tradicional sobre la formación del cortesano había entrado en crisis y que habría de tender hacia una doble moral que ponía en tela de juicio la unidad original del ideal de educación ${ }^{26}$.

Lo que hay de manual del Cortesano en este texto podría hacer pensar en el famoso texto de Castiglione. Sin embargo, es muy distinta la tradición a la que se remiten los diálogos del manuscrito de López de Vega. Al referirse a los Coloquios erasmianos, Marcel Bataillon ha mostrado la múltiple tradición de que disponían los escritores españoles:

${ }^{25}$ Los títulos de los capítulos dialogados ya muestran los temas que se tratan: "La diferencia de la sangre i de los nacimientos, ni tiene verdad en la naturaleza ni es más que una vanidad ridícula al verdadero filósofo", "Las insignias honoríficas, la administración del govierno i magistrados públicos, más son incomodidades que honores, i assí, el apetecerlas como el gloriarse en ellas, es manifiesta lesión de juicio", "La professión de las armas, tan gloriosa, según la razón política, es, según la natural, una brutalidad indigna de hombres, i el valor militar, según la misma, se deve antes llamar fiereza que valor", "Lo que comúnmente se llama honra es la tiranía más loca i el saber despreciarla será la comodidad más cuerda" y "En las contiendas literarias, más desayuda que aprovecha la modestia, i el que no se hiziere temer con el modo no se hará estimar en la sustancia".

${ }^{26}$ BLÜHER, op. cit., p. 507. Sobre la "doble moral" el autor dice que "en el siglo Xvn, en cuanto a la moral del cortesano, se abrió un abismo que separaba la ética tradicional cristiana de las reglas de sagacidad de política tacitista, que se intentaba salvar, como típicamente lo prueba Fernández Navarrete, haciendo una distinción entre la virtud interior, privada, y la exterior, política. La idea de una doble moral fue adquiriendo poco a poco carta de ciudadanía en los sistemas de educación cortesana de aquel tiempo, promovida, a no dudarlo, por las tendencias políticas del absolutismo español" (op. cit., p. 510). 
Los tratados que se escribieron bajo el impulso directo del moralismo erasmiano constituyen una especie de anexo profano de la literatura de edificación. La producción humanística de que España es deudora a los erasmistas sería literalmente desdeñable si no se tuviera el derecho de incluir en ella una abundantísima floración de diálogos.

No quiere decir esto que Erasmo haya sido el maestro único del diálogo para los hombres de la época. Al lado de sus Coloquios, ellos tenían en su biblioteca los modelos antiguos en que Erasmo se había inspirado, y también algunos diálogos "recientes" que no debían nada a Erasmo... por la misma época en que Erasmo engrosaba de año en año su volumen de Coloquios, Castiglione formaba su Cortesano como Cicerón había formado su Orador, y sus famosos diálogos iban a ejercer en toda Europa una seducción capaz de rivalizar con la de Erasmo ${ }^{27}$.

A la hora de considerar las Paradoxas es obviamente la tradición clásica la que cobra peso. La tradición clásica en la visión humanista de Erasmo de Rotterdam, ya que en el texto de López de Vega se vuelve relevante una característica que Bataillon señala como propia del diálogo erasmiano:

El coloquio típicamente erasmiano se creó el día en que Erasmo se propuso dar como materia de estas conversaciones algo distinto de las acciones de la vida diaria, algo distinto también de simples discusiones de ideas que se levantan por encima de las contingencias del momento, es decir, el día en que introdujo en ellos observaciones sobre las costumbres, alusiones a los acontecimientos políticos, dardos satíricos apuntados contra individuos o contra categorías de hombres, confidencias o recuerdos personales, debates acerca de las cuestiones religiosas más candentes ${ }^{28}$.

Las “observaciones de costumbres", los "dardos satíricos apuntados contra individuos o contra categorías de hombres" y el tono irónico que aparece con frecuencia, son elementos que pueden encontrarse en las Paradoxas racionales. Acaso uno de los ejemplos más exacerbados sea la sátira de los cortesanos:

${ }^{27}$ Erasmo y España. Estudios sobre la historia espiritual del siglo XVI, $1^{\text {a }}$ reimpr., F.C.E., México, 1982, p. 643. Los "modelos antiguos" que inspiraron a Erasmo son claros: "El coloquio erasmiano procede... en primer lugar de la gran tradición platónica y ciceroniana. Los Banquetes de Erasmo, y en particular su Banquete religioso, hacen pensar en Cicerón más bien que en Platón" (loc. cit.). 28 Ibid., p. 644. 
Entrantes i salientes los veréis siempre en sus salas; siempre con semblante de afanados; siempre como de corrida, i algunas vezes con su legajo de papeles en la mano, y no sólo con ademán de confidentes, mas aun de cooperantes en el ministerio de los despachos, poniendo cuidado en no mirar derecho a ninguno de los que allí acuden a sus negocios, como que llevan el pensamiento embaraçado en cosa de más importancia. I si como acaso topan con la vista en algún conocido, no hazen más que passar corriendo, con aquello de: "Perdóneme v. m., que no puedo detenerme". La vez que se hallan en las conversaciones de por acá fuera, en qualquiera materia en que se hable procuran encaxar algo de su valimiento, o acomodando algún cuentesillo que los manifieste por validos, o algún dicho o sentencia de Don Fulano, su señor, que como allí la fingen i son ellos los autores, quando no sea disparate, nunca dexa de ser frialdad vulgaríssima (p. 71).

A tal punto la descripción es punzante y acertada que, al oírla, el Cortesano no puede sino reconocer: "Confieso que me han venido a la memoria algunos que conozco d'essa marca" (p. 72). En tanto retoma ese rasgo erasmiano, la escritura de López de Vega (y la posición que adopta respecto de la importancia de la razón) conecta sus diálogos con la tradición humanista y los convierte en uno de los textos en los que puede rastrearse el nexo cultural que comunica humanismo e iluminismo. En efecto, M.-L. Acquier dice que

La elección de los géneros en las obras de López de Vega es imitatio ciceroniana, seguidora del segundo renacimiento descrito por Fumaroli. En su primera obra en prosa, él compone un sueño a imitación del Sueño de Escipión de Cicerón; en todas impera el diálogo entre estilo ciceroniano y platónico, es decir un diálogo rico en digresiones y próximo a veces al monólogo, pero con una constante progresión dialéctica de los temas; remiten también sus Paradojas al modelo de las Paradojas a los Estoicos, homenaje significativo tributado al autor del De Oratore... La estrategia discursiva de López de Vega recoge unos tipos argumentales ya forjados en su época, y admitidos por las autoridades... Sin embargo, al lado de estos discursos de préstamo, y de manera paradójica, López de Vega repite las invectivas contra el argumento de autoridad. Se sitúan en la línea de cierta reivindicación humanista por el recurso a los modernos, pero también pueden establecer un puente con la época de los novatores, precursores del espíritu crítico ilustrado. De hecho, en el epistolario de Gregorio Mayáns, López de Vega 
merece varios elogios no sólo por su elocuencia, sino también por su crítica del argumento de autoridad ${ }^{29}$.

En este segundo aspecto la crítica ha cifrado en buena medida la modernidad de los tratados de López de Vega. Ejemplo elocuente de su crítica al criterio de autoridad es la última oración de las Paradoxas racionales: "Quédese como queréis a los vulgares el jurar en las palabras de los passados, i tenga facultad el que se hallare fundado para eximir su razón de la esclavitud de la autoridad" (p. 136). Más aún, López de Vega no sólo critica en toda su obra prosística el criterio de autoridad, sino que también evita con mucha frecuencia remitirse a las autoridades que utiliza: "No cabe duda de los conocimientos teóricos del autor, aunque no sea fácil rastrear sus lecturas en un texto horro de citas, a diferencia de tantos tratados de preceptiva o comentarios críticos de la época" ${ }^{30}$. Si es posible reconocer este procedimiento -el soslayar las referencias a las autoridades-como casi una constante, es porque forma parte de un enfrentamiento más amplio; aquél que el autor entabla con la erudición, a la que opone el conocimiento. De ella se desprende la diatriba contra cierta filología, encarnada en los "gramáticos" y en los "críticos":

Esta crítica contra la erudición corre pareja, particularmente en la segunda obra [Heráclito i Demócrito], con la denuncia de los estudios filológicos basados en la comparación de ediciones latinas y griegas de los textos antiguos. López de Vega se ensaña también en contra de los que llama "críticos", posibles representantes de la praelectio (explicación de texto), fundamento del estudio de la enseñanza jesuita. La crítica contra el exceso de las ciencias, que pasa a ser extremada en las Paradojas, remite a la aurea mediocritas o lo nada en demasía de la doctrina horaciana... Este sentido reviste más bien la mediocritas de López de Vega, no sólo meta educativa, sino también ideal social de medianía, conforme a la teoría aristotélica del justo medio social ${ }^{31}$.

Además, de un modo quizás aún más revulsivo, el autor sostiene la necesidad de someter a revisión las sentencias de las autoridades:

29 "Los tratados en prosa", pp. 100-101.

${ }^{30}$ Carlos Vaíllo, art. cit., p. 200.

31 ACQuier, "Los tratados en prosa", pp. 97-98. También Alfonso Castro SÁEnz se ha referido al desprecio de la erudición presente en el Heráclito $i$ Demócrito (art. cit., p. 11). 
...siguiendo en todo a ésta [la Razón], con amor tan esento de las pasiones de la autoridad, que cogiendo tal vez, como industriosas Abejas, lo puro de algunas flores de los escritos de aquéllos, sea sólo la sentencia la que nos haga fuerça, no el Autor, atreviéndonos, donde nos pareciere, á menospreciar lo fantástico, i vano de muchas de las suyas: y abraçando, sin respetos, solo lo conveniente, $\mathbf{i}$ conforme a la razón natural, cierta, $\mathbf{i}$ universal madre de todas las ciencias ${ }^{32}$.

La autonomía otorgada a la razón conlleva en los tratados de López de Vega una notoria secularización: "el juizio libre, que se halla señor de la materia, mal se acomoda a discurrir por la fe, en las cosas humanas"33. Éste es también, lógicamente, uno de los rasgos en los que se manifiesta la modernidad de las $\mathrm{Pa}$ radoxas racionales:

Presúmese (dizen) que apadrinará el Cielo a la mayor razón i dará mejor sucesso al que la tuviere. (No le faltava más al Cielo que autorizar con su patrocinio los medios errados de que se vale el furor de los hombres!)... Ni la:justicia ni la Providencia divina se deve regular en el juizio humano, a nuestro modo. Favor podrá ser muchas vezes lo que nos parece castigo, i castigo lo que tiene semblante de favor... No hay, en quanto a lo temporal, por qué dar entero crédito a las apariencias. Los duelos, finalmente, por ningún lado pueden dexar de ser bárbaros, i exceptuando los ordenados o inspirados por el Cielo (de que hay algunos exemplos en las divinas letras), por ningún lado también puede ser honra, sino tiranía loca, su barbaridad (pp. 119-120) ${ }^{34}$.

32 Héraclito i Demócrito, p. 9, apud BLÜHER, op. cit., p. 512. Karl A. Blüher relaciona la crítica al criterio de autoridad con el estoicismo y agrega que López de Vega, "del mismo modo que Séneca, opone la independencia de su pensar a la mentalidad gregaria de la multitud. No conocemos a ningún español que en el siglo xvn, antes de López de Vega, haya proclamado tan expresamente la autonomía de la razón natural como principio de la conducta moral" (op. cit., pp. 512-513).

${ }^{33}$ Heráclito i Demócrito, p. 10, apud BLÜHer, op. cit., p. 512. La relación entre la primacía de la razón inferida del estoicismo y la secularización es casi inevitable: "En torno a este primer tema -la Nobleza- surge la cuestión del verdadero fin del hombre y Demócrito no se hurta a acatar la «luz revelada» pero él se aviene «con lo temporal y dejando aparte lo eterno», para llegar a la conclusión de que es el procurar «estar sujeto a menores miserias, a gozar con menos peligros y más sosiegos, lo posible de los breves y escaso bienes de la mortal Vida» (Heráclito i Demócrito, p. 57)" (GARAGorRI, art. cit., p. 113).

${ }^{34} \mathrm{La}$ actitud de López de Vega respecto de los duelos se ha modificado en su último tratado. Refiriéndose a El perfeto señor y a Heráclito i Demócrito, 
En el fragmento citado, la salvedad de los "ejemplos de las divinas letras", que se hace después de haber sostenido que "los duelos por ningún lado pueden dejar de ser bárbaros", parece obedecer más a una prevención respecto del Santo Oficio que a una verdadera convicción. El Filósofo dirá inmediatamente que los duelos atentan contra los tres tipos de leyes: la divina, la natural y la civil. De todas formas, es constante y notoria la distinción de un ámbito secular como materia tratable, que desestima la ley divina. Así, por ejemplo, cuando el Filósofo se dispone a argumentar las conveniencias de vivir según los dictados de la razón natural, desestimando los honores superfluos -los propios de la política-, hace la aclaración de que va a "ponderar sólo las conveniencias temporales, que es lo que propuse al principio del Discurso, dexando aparte, por no ser del punto, lo que a lo divino llaman espiritual por antonomasia, porque no bolváis a presumir que os quiero tapar la boca con lo beato religioso" (p. 67). Nunca el Filósofo había recurrido a lo "beato religioso" y de nuevo la aclaración parece prevención del escritor.

Así pues, se observa en la obra de López de Vega un proyecto didáctico implícito en el uso del diálogo. En particular, en las Paradoxas racionales, ese proyecto didáctico está subrayado en la paulatina argumentación que el Filósofo da de cada uno de sus "desengaños" con que instruye y convence al Cortesano. Esta didáctica implícita en la forma del diálogo va de la mano con lo que, en el prólogo, el autor llama "este desahogo de hablar claro" (p. 8). No se trata sólo de las verdades y desengaños que el autor propone ${ }^{35}$; es también una afirmación sobre su propia escritura.

Acquier dice que en ellos "la función militar del noble justifica también los ejercicios corporales. En el segundo tratado, en que el estudio de las materias educativas ocupa diez de los catorce capítulos, no se mantiene la necesidad de los ejercicios corporales parajustificar la función militar, sino para defenderse en caso de duelo si no se puede evitar. No se expresa ninguna condena moral del duelo -tan presente en cierta literatura moral coetánea-, sino la prevención que requieren las afrentas posibles. Se comprueba una vez más la fuerte implantación de la nueva relación poder/saber en la representación de la nobleza, en que la valoración de las letras dignifica la función gubernativa mientras queda descartado el ideal del soldado gentilhombre glorificado por un Garcilaso o un Cervantes" ("Los tratados en prosa", p. 97). Véase también José Luis Bermejo Cabrero, "Duelos y desafíos en el Derecho y la Literatura", en Francisco Tomás y Valiente et al., Sexo barroco y otras transgresiones premodernas, Alianza, Madrid, 1990, pp. 109-126.

${ }^{35}$ Aunque también se refiere a ellos, sin duda. La mención de su vejez (y 
En efecto, de su estilo Buceta destaca la "expresión sin rutilantes ostentaciones, antes al contrario, distinguida por placentera sencillez -en contraste con el conceptismo que por aquel entonces privaba en nuestra prosa-y agrado genuino: de una prosa que si carece de brillantez y colorido deslumbrantes, posee, en cambio, cuidadosa precisión, suavidad y sentido del matiz" (p. v).

Pero debe tenerse en cuenta que esta "sencillez" de la escritura, aparentemente tan ajena a las características propias del barroco literario español, forma parte de una tendencia muy frecuente en la época. Como ha mostrado José Antonio Maravall, se relaciona con el intento de distinguirse del modo culto en que discurrian los que, desde las capas más bajas de la sociedad, ascendieron socialmente hasta convertirse en letrados ${ }^{36}$ :

También en 1617 decía Suárez de Figueroa -en plena eclosión de la dificultad barroca- que las obras literarias en las cuales se da una parte principal al artificio y a la agudeza -dos valores que, aleccionados por Gracián, estimamos como superlativamente barrocos- son sólo propios de y para personas comunes, lo que el autor hace equivalente a personas de la ciudad ${ }^{37}$.

acaso el hecho de no encontrarse en el final de su vida bajo la égida de ningún protector) es una suerte de "excusa" a partir de la cual el autor expone su doctrina seguramente sin los "cuidados" de los tratados anteriores.

${ }^{36}$ Véase J. A. Maravall, La cultura del barroco. Análisis de una estructura histórica, $3^{\mathrm{a}}$ ed., Ariel, Barcelona, 1983, pp. 181-195 (sobre la expansión de las clases medias, esp. pp. 186-187); allí, a raíz de su exposición sobre el carácter masivo de la cultura del Barroco, el autor desarrolla una discusión sobre el uso del término kitsch en la crítica cultural (y sobre la aparición histórica del fenómeno) que resulta fundamental para reconsiderar el lapso histórico en el que se desenvuelve el surgimiento de la masscult sin reducir el proceso a sólo algunos medios de producción simbólica olvidando la importancia extrema que tuvo la imprenta.

37 Ibid., p. 208. Véase también lo señalado por la editora de El pasajero a raíz del prólogo: "Durante el Renacimiento y el Barroco se insiste en señalar las diferencias entre el «vulgo» y el «discreto lector», siendo muy frecuentes los libros con doble prólogo. No es este el caso, porque Figueroa ha eliminado la primera parte. Sin embargo, a lo largo de la obra se podrá observar su actitud despectiva hacia la plebe" (Cris tóbal SuÁrez de Figueroa, El pasajero, ed. M. I. López Bascuñana, PPU, Barcelona, 1988, p. 56, n. 1). Fue M. Menéndez Pelayo el primero en indicar la relación entre López de Vega y Suárez de Figueroa al presentar al primero como un "ingenio estoico, cejijunto y severo, gran senequista, y muy semejante al Dr. Suárez de Figueroa en lo malhumorado y en la fuerza sentenciosa de su estilo, autor de una serie de ensayos filosóficos que... son uno de los postreros destellos de nuestra buena prosa" (Historia de las ideas estéticas, $2^{\text {a }}$ ed., t. 3, pp. 421-422, apud Buceta, p. xii). 
Esta actitud, que tiene por objetivo separarse del vulgo, no era en absoluto nueva; por el contrario, se remonta a finales del siglo Xvi: "Mirad que los príncipes y señores grandes hablan con gravedad y simplicidad alta; y mirad la gente menor quán aguda es en sus conceptos y dichos que, assí como hienden el pelo, hienden la oreja con la agudeza de ellos"38. Además, se trata de una actitud muy coherente con la posición neoestoica, según senala Otis H. Green: "ignorance is the characteristic mark of the vulgo" y, a la vez, "the vulgo is the antithesis of the Stoic sapiens" 39. Creo que a la luz de este punto de vista puede entenderse la posición de López de Vega frente al gongorismo:

Es su mayor atención llenar los Versos de vocablos de boato ignorando quantas vezes consiste la Elegancia en saber airosamente declinar las cumbres y caminar con paso moderado por lo llano i quánto dista lo túmido de lo grave quanto sea necesario el subirlas. De los pensamientos cuydan poco... Qualquiera locución o palabra común condenan por humilde, confundiéndolas con las triviales y plebeyas, sin advertir la diferencia que ay de unas a otras; i que como a estas deve huir la decencia, no puede la perspicuidad escusar aquellas... ${ }^{40}$.

Es importante notar que distingue lo humilde de lo trivial o lo plebeyo. La distinción mantiene la oposición a lo vulgar y permite buscar -en este caso como en tantos otros- el justo medio entre lo plebeyo y su opuesto. Ya que, en la que denomina "guerra civil entre el [estilo] antiguo y nuevo"41, López de Vega se mantiene equidistante de cultistas y anticultistas y adopta una posición intermedia. También son criticados los anticultistas que,

Paliando... la desmayada i abatida floxedad de su vena, protestan aborrecer la inchada i áspera oscuridad, y tuercen con tal desor-

${ }^{38}$ López Pinciano, Philosophia antigua retórica, II, p. 208, apud MARAvall, op. cit., pp. 207-208. La relación de López de Vega con López Pinciano también se manifiesta en la importancia que el último daba a la razón como instrumento de evaluación de las sentencias de los clásicos: "sin Rhetórica ay retóricos; y sin Poética ay poetas; sin arte Lógica ay lógicos naturales; q[ue] el hombre tiene el vso natural de la razón, el quel es la fuente de todas las cosas" (Philosophia antigua retórica, I, p. 10, apud SANFORD SHEPARD, El Pinciano y las teorias literarias del Siglo de Oro, $2^{\mathrm{a}}$ ed., Gredos, Madrid, 1970, p. 143).

${ }^{39}$ OTIS H. GREEN, art. cit., p. 193.

${ }^{40}$ Heráclito i Demócrito, pp. 180-181, apud VAíllo, art. cit., p. 204.

${ }^{41}$ Prólogo "A los lectores", en Lirica poesía, apud VAíllo, art. cit., p. 203. 
den el camino contrario, que en son de buscar i amar lo claro y lo suave se abrazan con lo humilde i sin nervios. I aunque no les falta a vezes la blandura son los sentimientos, las locuciones y las vozes tan plebeyas que la vienen a estragar i hazer ridicula. Nunca levantan el pensamiento a conceto más que ordinario. Nunca excede la elegancia con que le declaran de la que usan en la conversación doméstica ${ }^{42}$.

No es casual esta suerte de ejercicio de crítica literaria con que López de Vega analiza la poesía contemporánea. Encontramos en el autor un alto grado de conciencia sobre la especificidad de la literatura. De hecho, como señala Carlos Vaúllo, "no deja de sorprender en un moralista -pues eso es básicamente al margen de sus aficiones literarias-que despoje a la poesía de

42 Heráclito i Demócrito, pp. 180, apud Vaíllo, art. cit., p. 203. Acaso la poética de López de Vega no esté exenta de connotaciones políticas. Un manuscrito escrito en 1643 por el jesuita sevillano Ávila y Sotomayor analiza dos panfletos que circularon a raíz del intento de enjuiciar a Olivares; uno, de Andrés de Mena, atacando al Conde-Duque y otro, un anónimo titulado Nicandro, defendiéndolo. Sobre ese manuscrito, Francesco Benigno dice que: "Un elemento curioso, aunque no carente de interés, es la explicación del nombre Nicandro que ofrece el jesuita, para el cual hace referencia, amén de al autor de Alexipharmaca, también al Antidoto, un polémico escrito de Juan de Jáuregui contra las Soledades de Góngora: «El de Antídoto le tomó de un escrito vulgar, que sacó Don Juan de Xáuregui contra Don Luis de Góngora, ahora treinta años, y debiera el autor del Nicandro huir este título por ominoso; pues no salió a Don Juan mucho meior aquel papel, que éste le ha salido al que le escribe». La hipótesis del padre Ávila, que era cultivador de poesía y autor de rimas..., no es en absoluto peregrina: el autor del Nicandro pretendía probablemente aludir a la hinchazón expresiva de la poesía de Góngora, considerada por Jáuregui como capaz de despertar inmoderadas pasiones y por ende corruptora del ánimo; y a la conocida contraposición entre oscuridad gongorina y claridad propugnada por Lope" (La sombra del rey. Validos y lucha política en la España del siglo XVI, Alianza, Madrid, 1994, p. 207, n. 40). La facción política a la que se adscribía Jáuregui era clara: "Es por lo demás bien sabido que Jáuregui, que había recibido en 1621 el cargo de censor público, estaba estrechamente ligado con Olivares, a quien habia dedicado diversas obras (el Discurso poético de 1623, el Orfeo de 1624 y la Apología por la verdad de $1625 \ldots$... y gracias a cuya protección había sido ascendido en 1626 al oficio de caballerizo de la reina" (loc. cit.). A estos motivos "políticos" de posible enfrentamiento podrían sumársele otros "ideológicos": Juan de Jáuregui, en su comedia El Retraído se había burlado de la tesis neoestoica que Quevedo propone en La cuna y la sepultura sobre la dependencia de Epicteto respecto de Job, que a su vez había defendido el jesuita Juan Eusebio Nieremberg, Rector del Colegio Imperial en Madrid (véase BLüHer, op. cit., pp. 466-467). 
su carga moralizante" ${ }^{33}$. Éste es un aspecto más en el que puede verse la discusión con el criterio de autoridad y la modernidad de la obra de López de Vega: "al asignar esferas distintas y autónomas a la poesía y a diversos discursos doctrinales y especulativos, el autor parece anticiparse a una evolución posterior de la literatura, libre de imposiciones horacianas" 44 .

En las Paradoxas morales, la reflexión sobre los procedimientos propios de la práctica literaria, las "Estratagemas... i razones de Estado de [1] escritor", se percibe desde la primera página. Pues ya en el prólogo, dirigido "a los censores", el texto llama la atención por su carácter metadiscursivo. El destinatario elegido $^{45}$ muestra un grado elevado de conciencia sobre las mediaciones entre autor y público y un intento de poner en primer plano los requisitos necesarios para que el texto entre en circulación en una sociedad en la que los libros deben ser aprobados por la censura. Muestra, más aún, una mirada irónica que tiende a eludir la "materia" -o hacerla irrelevante-y volverse autorreferencial:

Censor, bueno o malo (que para mi atención todo es uno), ya yo llevo previsto el diente con que puedes morder estos papeles. Pero ni dél ni de ti se me da nada, que me hallo ya en estado de no temer censuras, porque no escrivo por ambición de gloria, sino por otro fin menos generoso, aunque también menos vano, que no es más, en buen romance, que variar la ociosidad. No escuso, con todo (por estar assí puesto en uso), darte cuenta de la razón, o razones, por qué determinando sacar a luz pública algo de nuevo hize singular elección de paradoxas. De algo nos ha de servir el prólogo, porque si no, ¿para qué era este pedaço de prosa?

Entretengámonos, pues, un rato (p. 5$)^{46}$.

${ }^{43}$ Art. cit., p. 201.

44 Ibid., p. 202. Hav, a este respecto, una diferencia con Lope de Vega: "En la práctica, Lope había aceptado la función didáctica que los teóricos otorgaban a la literatura, doctrina ésta que como se recordará, estaba asociada a la teoría política en la mente de los críticos" (SHEPARD, op. cit., p. 179).

${ }^{45}$ No encuentro referencia a los "censores" como posibles destinatarios del prólogo, ni a López de Vega, en los trabajos de Alberto Porqueras Mayo, El prólogo como género literario. Su estudio en el Siglo de Oro español (anejo 14 de la RLit, 1957) y El prólogo en el Manierismo y Barroco españoles (anejo 27 de la RLit, 1968).

${ }^{46} \mathrm{Al}$ finalizar el prólogo, el autor volverá a referirse al acto de escribirlo: "Cerremos assí la cuenta que ofrecí darte de mis intentos; i porque no se me ofrece cómo despedirme, i no hazerlo tan a secas -aunque esta no es oración, sino un razonamiento llano-, préstenme su ordinario Dixi los oradores, pues 


\section{LA "DESENGAÑADA LUZ DE LA RAZÓN"}

También en el prólogo el autor enumera una serie de "ofensas" que prevé que causará su libro. "Sufran -dice-los que en [las Paradoxas] se hallaren ofendidos que conozcamos los pocos a quienes ofenden más, la razón, siquiera, de nuestra quexa, que en esto viene a parar toda la vengança" (p. 7). Los probables ofendidos son "el ilustre", "el constituido en dignidad pública", "el brabo", el "supersticioso observante de los puntillos de la honra" y "el ingenioso, o erudito de boato" (pp. 7-8). Pero si bien es cierto que estas ofensas y estos desengaños conllevan un planteo filosófico, de un modo menos notorio la "quexa" también trae aparejada una serie de posiciones políticas. Claro que no aceptaría el autor denominarlas de ese modo, puesto que en su libro "política" se opone a "naturaleza" y "razón". Encontramos aquí un uso del término "política" muy propio de la época, cargado con el peso de la sanción moral hacia el tacitismo y el maquiavelismo, que puede verse también en Pedro de Ribadeneyra ${ }^{47}$. Sin embargo, el pragmatismo, que es uno de los rasgos que los contemporáneos más notaban y sancionaban en el maquiavelismo, recorre el texto de López de Vega:

este moralista lleva a cabo una síntesis de dos ideologías, la filosófico-vital del Neoestoicismo y la política del tacitismo, con la ayuda del principio de doble moralidad. El hombre íntimamente estoico, ciudadano del mundo... en la farsa de las apariencias de la vida... hace el juego ateniéndose a las reglas de la vida cortesana ("por no hacerse singular i odioso se conforma con la ley política i con la costumbre cortesana que lo ordena...", Paradoxas, p. 112).

para estotros fines no se ha inventado fórmula, sino el que haziendo esto epístola nos valgamos del ordinario Valete" (p. 9). No me parece imposible pensar que en este último párrafo López de Vega se burle de las poéticas de Francisco Cascales (Tablas poéticas, 1617) y de Jusepe Antonio González de Salas (Nueva idea de la tragedia antigua, o ilustración al libro de la Poética de Aristóteles, 1633), en los que, además de volverse sobre el criterio de autoridad -sea Horacio, sea Aristóteles- como fundamento indiscutible que López Pinciano había relativizado, cobra suma importancia el método del orador como modelo (véase SHePaRd, op. cit., pp. 151-176).

47 Tratado de la Religión y Virtudes que debe tener el Principe Christiano para gobernar y conservar sus Estados. Contra lo que Nicolás Maquiavelo y los políticos de este siglo enseñan (1601). Véase CÉsAR Silió CoRTÉs, Maquiavelo y su tiempo. Repercusión del maquiavelismo en la teorias y en las prácticas de gobierno, EspasaCalpe, Madrid, 1946. 
La filosofía estoizante de la vida se oculta bajo la máscara de la sagacidad mundana de la política. Al producto de esta precaria unión de verdad y apariencia, ética y acomodación lo llama López de Vega "filosofo activo, varon civil, i cortesano", o también "Prudente Jovial, Sabio tratable; i Filosofo... de Capa i Espada" 48.

En efecto, es posible reconocer en las Paradoxas racionales la presencia constante del pragmatismo, tan propia de la época. El razonamiento del filósofo, a menudo, recurre a ese criterio más que a ningún otro para argumentar:

pero declaro (porque no presumáis argüirme de mal filósofo) que no es mi intento determinar en esta doctrina lo que es más honesto, sino descubrir lo que en la materia que disputamos suele ser más útil; i diziéndolo más llano, no lo que según buena razón devía ser, sino lo que según la depravación del siglo es entre nuestros Hespañoles más ordinario i contingente (pp. 128-129) ${ }^{49}$.

El pragmatismo, que no se opone a la ética del neoestoicismo del siglo XVII ${ }^{50}$, no es sólo el fundamento de la argumentación, es también lo que regula el comportamiento ideal que el libro propone:

Antes, si las conveniencias le han de venir del crédito, las podrá esperar mejor del que suele resultar de la moderación i de la prudencia que de la estimación de la pompa vana. Si la falta fuera de lo necessario, ningún cuydado o diligencia dixera yo que se le podía condenar, i le permitiera sólo la vergüença si por descuydo o flajedad se dexara padecer o llegara a mendigar; mas por todo lo que sobra de lo inescusable ninguna molestia voluntaria dexa de ser reprehensible, i assí ninguna omisión puede ser vergonçosa (p. 108) ${ }^{51}$.

48 BLÜHER, op. cit., p. 517.

${ }^{49}$ Buceta anota que con este fragmento citado comienza una parte del texto agregada "en una hojilla suelta pegada al margen izquierdo" (p. 129, n. 1). Acaso esta declaración de principios ni este comentario sobre los españoles hayan sido presentados a la censura.

${ }^{50}$ JeREMY Robbins señala que "Scepticism played a pivotal role in Spain, as elsewhere in Europe, in fostering more secular, pragmatic, and scientific modes of thought" (art. cit., p. 137).

${ }^{51}$ Por su parte, AcQuier opina que "sin desestimar el tono a veces mordaz de López de Vega, se impone un pragmatismo muy fuerte en el trato social, presente sobre todo en las dos últimas obras. Del ideal del noble perfecto, que no deja de ser modelo -con la dimensión normativa que sobreentiende-, 
La búsqueda por satisfacer la necesidad y el objetivo de la conservación son a tal punto importantes que, aún cuando el filósofo argumenta por qué los hombres racionales deben desestimar los cargos públicos, justifica ese trabajo si las circunstancias lo exigen: "yo no condenaré la aplicación al ministerio público, que si no hay otro medio para passar la vida, o no tan a mano como ésse, locura sería también el querer que uno se dexasse morir o eligiesse el vivir muy desacomodado por no trabajar lo que pudiesse sin matarse" (p. 70). Esta justificación, que hace pensar en una reflexión autobiográfica de López de Vega, connota fundamentalmente la presencia de un sector social que busca abrirse paso por medio del ingreso a la burocracia estatal.

Aun cuando se elogian y recomiendan las virtudes estoicas -y cristianas- que se oponen a las prácticas propias de la corte, surge la concesión que reconoce el poder. Así sucede por ejemplo cuando el filósofo habla de la modestia:

No hay virtud oy más desaprovechada, principalmente entre hespañoles. No sirve de más que de dar licencia a los insolentes. I aunque atendiendo a lo honesto nunca deve dexar de ser estimada como virtud, si se atiende a lo vtil (que es el fin de nuestro discurso), buelvo a decir que no hay, para las controversias que oy se ofrecen en las conversaciones, virtud más desaprovechada, porque es experiencia cierta que no se granjea con ella crédito o estimación alguna, antes se ocasionan mohinas i desayres, animándose igualmente los doctos i los indoctos a impugnar sin respeto al que la usa. I assí, el que se hallare tan estoico que no haziendo caso de vtilidades ni de estimaciones se determinare a no aspirar en nada a otro fin que a observar rigurosamente todas las virtudes, abrace enhorabuena esta de la modestia i hágale sacrificio de las pérdidas, que por más benevolencia que d'ella le resulte, en lo que toca al punto del respeto, no tendrá poco en que hazer sacrificio meritorio (p. 132).

Karl A. Blüher ha mostrado que la "doble moral" procede de la adaptación barroca del estocismo. Se trata de una "moral conformista de amoldamiento hacia fuera; moral independiente, fundada en el derecho natural, hacia dentro": 
Antonio López de Vega... dio un nuevo giro a la doctrina de la doble moral al no distinguir ya entre una moral privada de signo cristiano y una moral externa, tacitista, complemento de la otra, sino al aceptar una moral externa conformista y otra moral interna que, en vez de derivarla de la doctrina cristiana tradicional, basó en la autonomía de la razón natural, y eso valiéndose visible y considerablemente de la ética estoica ${ }^{52}$.

Esta "doble moral" puede sin duda relacionarse con la secularización presente en el discurso de López de Vega, ya que la separación entre una "moral externa conformista" y una "moral interna" basada en la razón natural, supone la escisión de una lógica religiosa -acorde con la contrarreforma- de otra secular. De alguna manera, hay aquí un anticipo de la doctrina de la "doble verdad" que sobre todo a partir del siglo xvin se usaría para mantener la doctrina católica a salvo de los problemas que la racionalidad iluminista planteaba ${ }^{53}$.

Pero más aún puede relacionarse la "doble moral" con el contexto político en el que se desenvuelve; se trata de ocultar las creencias individuales de la presión social ejercida por lo que Maravall ha llamado "una cultura dirigida". De modo análogo, la insistencia en el "desengaño", que en principio surge del neoestoicismo, remite a una serie de "engaños" no siempre explícitos en el texto: las estrategias del Estado.

La presión social resulta tan poderosa que, aun cuando el Filósofo recomiende el desprecio de la opinión común y una conducta que se guíe según la "razón natural" en vez del comportamiento corriente en la corte, igualmente hará las indicaciones

52 Un pasaje de Heráclito i Demócrito demuestra lo dicho por Blüher: "como en la Religión ay dos especies de culto, interior el uno, i el otro exterior: ay también en los respetos, i veneraciones humanas la misma división. La interiorveneración bien confieso, que sólo a la virtud, ó intelectual, ó moral, la debe el sabio. Pero a la exterior, como sea moderada (supuesta la costumbre del Mundo) os obligan la vida civil, i la necesidad de conservaros: i quando lo estienda a razón alguna de utilidad (no pecándose en el exceso, de que después nos reiremos) no dexaré de ser buen filósofo" (pp. 13-14, apud BLÜHER, op. cit., p. 513).

${ }^{53} \mathrm{Ni}$ el iluminismo ni la idea de una "doble verdad" se difundirían sin conflicto. Así, por ejemplo, en su libro La ilustración en el Río de la Plata. Cultura eclesiástica y cultura laica durante el Virreinato (PuntoSur, Buenos Aires, 1989), José Carlos Chiaramonte ha recopilado, entre otros documentos, un índice jesuita de las ideas cartesianas cuya enseñanza quedaba prohibida por no ser compatibles con la fe. 
necesarias sobre cómo simular. El objetivo del "hombre racional" es conjugar el estoicismo y el proceder propio del cortesano:

Quédense, pues, a los otros los cuydados i la costa, i a nuestro varón la carne sin hueso. Mirad si es comodidad el no hazer casso d'este puntillo. I no lo será menos el menospreciar también esotro de que no le vean comprando algo en las plaças públicas; entendiéndolo con la misma epicheya de que ni sea cotidian ni las cosas gruesas, como pan i carne (que siempre es decoroso que se deseen a los sirvientes, i no fuera tampoco comodidad, sino molestia, el ir a ellas en persona, excepto en la ocasión de algún particular antojo o general aprieto de los temporales), sino las de regalo i gusto, en que la gente servil no suele tener tan buena elección, ni hallar tan probable el respeto que se la dexe hazer. I aun en éstas, sabiendo cautivar la grossería interessable de quien las vende, con estender la mano i ofrecer algo más de lo que se pide, o con dexar el pedirlo a su arbitrio, que nunca suele ser con tanto excesso que haga mella considerable en la bolsa más vazía. Granjéase con esto el gozar con ventaja los regalos possibles, i siendo la materia más de delicia que de necesidad, aun a los vanos o se les haze tan feo el acudir personalmente a ello, con que se viene a conseguir la conveniencia sin la desestimación común (p. 111).

Por medio de esas tácticas, que en el ejemplo anterior le dan a "nuestro varón" una no buscada reminiscencia de picaro, se pueden congeniar las creencias personales con los ritos sociales. Puesto que es inevitable el contacto y el trato con los cortesanos, las estrategias de simulación deben considerar el modo de evitar las consecuencias de su comportamiento irracional. El recurso del "desengañado", llamativamente, es la simulación por medio del lenguaje:

Pero quando por razón de oficio o conveniencia alguna no pueda dexar de tratar con otros i el descuido o algún coraje casual le trayga a la boca alguna extravagancia que sea mal recibida, i no pudiendo equivocarle el sentido (que será el mejor consejo)... el más seguro desvío será mudar de plática i mostrar que no se haze caso, o con aquello de: "Bueno está, passemos a otra cosa; que esto no importa tanto como importará el amohinarnos", o con otro terminillo igual i dicho a media risa (p. 115).

Llegado el caso, entonces, ante el cortesano ofendido que desee defender su honra por medio del duelo, el "desengañado" deberá hacerse el desentendido: 
De un cuerdo vamos hablando, i assí no queda la suposición violenta, que a un loco no hay que aconsejarle ni que estrañar que lo yerre todo. Pero como los descuydos aun en el más cuerdo son contingentes, i contingente también como el primer movimiento alguna palabra de menos estimación en el calor de las controversias, i baste cualquiera de estas causas (por leve que sea para los entendidos) a ocasionar a los que enferman de bravos, hazemos possible el caso i buscámosle salida de buen ayre con que, menospreciándole el puntillo de la honra, se quede con decoro i sin el descrédito de la sospecha de pusilanimidad. La chança será, sin duda, la que consiga este efeto (p. 122).

"Con decoro y sin el descrédito". No sólo es importante evitar el desafío con que un loco quiera resarcir la ofensa para preservar la vida y resguardar la comodidad sino que al mismo tiempo es necesario sortear la "sospecha de pusilanimidad". El filósofo explica detenidamente cómo lograr ese efecto:

Muchos desenfados se pueden ofrecer en la ocassión a este modo, que desanublen el ceño del ofendido i hagan gracejo el enojo. I quando con urbanidad se confiesse el descuydo o la inadvertencia de la palabra que dió el motivo, i aun quando se responda galanteando sobre la valentía: “CCómo? Perdone v. m., que no pensé lo havía con un hombre tan bravo. No faltava más sino que por esto nos matáramos. Sea lo que v. m. quisiere. Digo que hablé por boca de ganso", i otros terminillos semejantes, dichos con media carcajada, para con ninguno de los que bien sienten quedará con nota, sino antes con aprobación al retado, i bastarán semejantes votos para sanear su crédito i conservar en la opinión común su estimación (pp. 122-123).

Como puede verse, el principio que rige el accionar propuesto no es solamente el de conservación propio del estoicismo. Hay además el intento, por medio de cierto histrionismo preparado y recomendado, de mantener una reputación; es decir el reconocimiento de que ésta es necesaria en la vida en la corte. La preocupación se repite con frecuencia y, junto con la ironía y el desprecio ("en saber menospreciar todo lo que en la materia determinare vuestra honrilla consiste, no digo ya la virtud moral, mas también la legítima comodidad. I si se haze... con modo cortesano, aun con los muchos será posible conservar la estimación", p. 118, las cursivas son mías), suele aparecer el reconocimiento del poder de la palabra para disfrazar y transformar lo real: "el desenfado i cortesanía 
de una respuesta aun al mismo temor puede hazer hermoso, quanto más desmentirlo" (p. 121).

\section{LA “RAZÓN DE LO INCIERTO”}

El tópico de la simulación, tan propio de la época, también aparece en las Paradoxas racionales bajo la forma de la simulación del gobierno civil: "necessario es este i otros engaños semejantes al gobierno político de las Repúblicas... Pero no porque convenga que haya engañados me convendrá a mí, ni a otro como yo, el ser uno d'ellos" (p. 60). Vale decir, la simulación y el engaño son procedimientos necesarios del gobierno y de la política. Pero frente a la multitud de "engañados", el filósofo reclama para sí el derecho de observar esas estrategias como lo que son, como recursos del poder temporal. Cabe imaginar que, como el autor conoce demasiado bien el ámbito cortesano como para que pretenda engañárselo con el argumento de la nobleza de sangre. El tópico de la corrupción propia de "este siglo" se convierte en una crítica de la nobleza:

...no es firme ni constante prueva de ser natural la nobleza o vileza de sangre. Essa conjetura que, por lo que dezís que más comúnmente sucede, queréis sacar de las inclinaciones i costumbres, antes nos va en lo más ilustre, obligando la corrupción del siglo a sacar de aí mismo contraria conjetura i prueva contraria de lo que pretendéis, pues siendo los de más alta esfera los que más escandalosamente viven (pluguiera al cielo que assí no fuera), algún indicio parece que nos dan de que con la sangre les viene naturalmente lo escandaloso, aunque lo más cierto es que procede de la mala educación que por la mayor parte oy tienen, pues en la excepción de algunos preservados del común contagio que vemos observantes de las leyes de la verdadera nobleza, quando se atribuya a inclinación natural, no será por ser prerrogativa particular de aquel grado, sino qualidad que puede ser común a todos los hombres (p. 39).

Las nociones de "corrupción" y "contagio", metáforas médicas de lo social que suelen estar asociadas a soluciones de tipo "quirúrgico", conviven aquí, en cambio, con la importancia atribuida a la educación. De todas formas, esta posibilidad de que "todos los hombres" tengan la "verdadera nobleza", que en principio parece acercarse tanto a la idea de razón iluminista, no implica ningún tipo de "democratización", puesto que con- 
vive con una idea elitista de los "desengañados", que "llevando seguro el conocimiento de la razón, no sólo dev[en] menospreciar el engaño, mas también los engañados" (p. 123) ${ }^{54}$. La mención de "verdadera nobleza", entonces, es en primer lugar un punto de apoyo para continuar la crítica a la nobleza que, por contraposición, se vuelve "falsa":

En altivezes i vanidades vienen (según lo más común) a resumirse todos sus bríos; no que los incite el verse en lugar alto a operaciones virtuosas, ni a querer por este camino parecer mayores. I assí, o las costumbres no han de valer para argumento de ser natural su nobleza, o si d'ellas se ha de sacar prueva de que es natural la diferencia, viene oy lo más ilustre a quedar naturalmente convencido de más vil, i adjudicada sólo a lo mediano (donde se conservan todavía los buenos respetos i proceder honrado) la verdadera i natural nobleza que los más poderosos quieren arrogarse (p. 40).

En segundo lugar, como puede verse, la crítica de la nobleza va de la mano de la reivindicación de "lo mediano", donde "se conservan todavía los buenos respetos i proceder honrado". Es evidente que está hablando de sectores sociales y que "lo mediano", la mediocritas, se refiere aquí a las clases medias. Y me parece también evidente que no se trata de un planteo filosófico sino político. De allí que el filósofo diga que mientras la nobleza no deje su comportamiento actual y viva virtuosamente, "ni yo ni ninguno de los que sienten desengañadamente la ha de tener [a la nobleza de sangre] por más que por una introducción i estratagema político" (p. 40). Es obvio que se trata de una estrategia. El filósofo no cree en la nobleza de sangre -ni tampoco el autor ni la clase social mencionada como "lo mediano"- sea cual sea el comportamiento que ella muestre. La razón se rebela a creer en ella. Así, el desengañado,

54 Véase también el siguiente ejemplo: "Pero si todavía instáis con la desestimación común i los incomodos que d'ella resultan, sirva de respuesta lo que allí también dixe: que ni es la multitud, sino sólo los entendidos que tienen este mismo sentimiento los que dan la verdadera reputación, ni aun con la vulgaridad de los muchos viene a perder el que en la elección de los amigos no atiende a más nobleza que a la de las inclinaciones i virtudes racionales; pues no teniendo éstas infalible sujeto donde assistan, assí en lo inferior como en lo superior o en lo mediano del orden civil, podrá suceder que se hallen, i probablemente se hallarán raras vezes en lo ínfimo, donde la buena educación no suele ser tan ordinaria... es la igualdad en la virtud la que se atiende" (p. 114). 
Reserve la entera i no simulada veneración para la verdadera i natural nobleza de la parte intelectual i costumbres racionales dondequiera que tal hallare, no haziendo caso para esto de las introducciones políticas, grados de la nobleza, diferencias de sangre o estimaciones comunes (p. 42).

Es notoria la exaltación de la "parte intelectual", que va de la mano de un elogio de su propia gloria: "se echa bien de ver que no havéis nunca provado quán grande gloria sea para un independiente el menospreciar estas superioridades que introduxo la política" (p. 44) ${ }^{55}$. En una suerte de variación sobre los tópicos de los géneros argumentativos clásicos (lo bueno para el discurso epidíctico, lo conveniente para el deliberativo y lo verdadero para el forense) el Filósofo dice que la ley política no se puede tener en nadie por indecente pero sí en los filósofos, porque los privaría de "los tres géneros de bienes que excogitaron [lo] honesto, vtil i delectable" (p. 45). Es lógico entonces que filosofía y política resulten prácticas contrapuestas:

reconocida la vanidad de la sustancia i mirada solo como treta i fullería para otros fines, podía passar su estimación [de la nobleza de sangre] como cosa permitida. Pero advierto de passo que esto se entienda no faltándoles a las utilidades, que le disculpen essa circunstancia de inexcusables, o a la necesidad, o a la decencia; que éstas son las que no desecha la cuerda Filosofía (p. 48).

Esta concepción, necesariamente, conduce a la modificación de la idea de fama:

Del lustre de la pompa vana (si por éste lo dezís) hago yo muy poco caso, i le cuento entre las vanidades ridiculas; si por el real y verdadero, esto es, por el crédito y aplauso de los merecimientos,

55 "La nobleza y virtud fundadas en la educación y en el estudio de la filosofía son temas que cobran su entera dimensión si se consideran las repetidas acometidas de López de Vega contra la nobleza de nacimiento. Aquéllas obligan a situarlo en la polémica entre nobleza natural y nobleza política. En El perfeto señor de 1626, la nobleza es una distinción «accidental» que recibió el individuo noble como herencia o para satisfacción de sus hazañas. La idea de una nobleza accidental basada en una concepción cristiana de la naturaleza humana, está ya muy presente en el siglo xvı y forma parte de un patrimonio común de la literatura de raigambre neoestoica... En Heráclito y Demócrito, el sistema de justificación de la nobleza está cambiando... El noble debe confirmarse con la ley civil, «la ley política»" (AcQuier, "Los tratados en prosa", p. 98). 
mayor le conseguirá el que por la singularidad d'estos escalones supiere arribar a alguna eminencia pública que el que para subir a ella no pudo alegar en su favor más que el haver nacido.

El cambio de la idea de fama cortesana por otra más adecuada al filósofo, al hombre racional, es explícito:

havéis de advertir que donde se tuviere noticia de su extravagancia [de los filósofos] se tendrá también de su saber i proceder honrado en lo sólido i verdadero; i nunca la fama d'estas calidades dexa de contrapesar a qualquiera nota de lo menos importante, antes suele dorar i hazer venerable lo mismo que en otro pasara (como dezís) por figurería (p. 106).

La posición que reivindica una fama despojada de las características cortesanas puede ser leída como filosófica, desde luego, pero -en tanto la fama "verdadera" que busca el filósofo se relaciona con su saber- no se debe soslayar el hecho de que también involucra una perspectiva política:

Ahora bien, cuando López de Vega escribe que la nobleza de nacimiento no es más que un accidente, fácil sería concluir que está reivindicando una nobleza de las letras. Pero limitar su pensamiento a esta reivindicación letrada sería desconocer la rivalidad entre aristocracia y letrados para los cargos administrativos de la monarquía ${ }^{56}$.

${ }^{56}$ ACQuier, "Los tratados en prosa", p. 99. La autora agrega inmediatamente que "también puede ser un discurso promovido por la propia aristocracia. No hay que olvidar que sus escritos salen a la luz en gran parte a su amparo. De ahí nace la ambigüedad fundamental de su postura" (loc. cit.). Sin embargo, cabe aclarar que se refiere aquí fundamentalmente al Heráclito $i$ Demócrito, libro para el cual su planteo parece sumamente atinado. Distinto es el caso de las Paradoxas racionales por varios motivos: en primer lugar porque la situación de la aristocracia había cambiado después de la caída de Olivares en 1643, en segundo lugar porque, como Acquier ha mostrado, para 1654 la situación de López de Vega había cambiado, ya no se encontraba al amparo de la aristocracia, en tercer lugar porque, como señala en el prólogo el autor, la "razón primera" para escribir las Paradoxas es "el querer assí desahogar el ánimo, que están cansados mis muchos años de tanto dissimular, i no haver dicho más de otra vez en tan largo tiempo (también en otros Diálogos) claro lo que sienten" (p. 5) y en cuarto lugar, oorque el libro permaneció inédito y no es desatinado pensar que las posiciones que en él se adoptan hubiesen contribuido a que quedase como manuscrito. 
En efecto, pueden encontrarse cantidad de pasajes en los que la idea de una fama verdadera y otra falsa se enhebra con la distinción del "hombre racional" tanto de la nobleza como del vulgo:

Como la fama sea del valor legítimo (aunque por ninguna diera yo dos passos, i la paz i tranquilidad del no conocido, como otras vezes he dicho, es para mí de mayor estimación que todas) para con lo más común de los hombres, bien disculparé que se tenga por gloriosa... i sin [la verdadera gloria] poco apetecible es la fama, a lo menos para con los que bien sienten, que es el intento de mi discurso; perdonen o no perdonen los Césares i Pompeyos, que al entendimiento libre ni las opiniones comunes ni la autoridad agena le hazen fuerça (p. 88).

Dado que la vanidad y la:jactancia de los cortesanos valoran la fama engañosa, es lógico que la ética del filósofo reivindique la necesidad de pasar inadvertido para vivir de acuerdo con sus ideales:

Pero no son éstos... los que quiero yo traer a exemplo, sino otros que conozco de más alta esfera i de costumbres más racionales, que retirados de todos los embaraços civiles, de oficios i de pretensiones, aunque no de la comunicación de sus amigos, saben vivir en medio de la corte, sin que en ellos se repare, professando, para con quien los conoce, tan patente el desengaño i la libertad natural tan desenfadada, que tratándose en todo como pueden i procurando también vivir en todo según la buena razón, ni se les da de todos essotros pundonores, ni por esso son desestimados (p. 105) ${ }^{57}$.

En íntima relación con la recomendación de pasar inadvertido aparece en el libro la idea de libertad. No ser visto ni oído es el mejor modo de conservar la libertad: "Por elección, señor

57 Hay en el Heráclito i Demócrito un episodio en el que se satiriza la necesidad cortesana de ser visto. Heráclito narra su inten to de conseguir audiencia de un ministro; después de fracasar al concurrir vestido como solía, cambió de táctica: "Disfraçado, como veis, entre tantas mentiras, acometí esta tarde á probar ventura. No me salió errada la cuenta... Entré en esta forma por el espacio del tal Ministro. Hizose sentir el estruendo de mis ruedas... Fue advertido el lucimiento del traje de los mismos ojos que la otra vez no avían reparado en la persona" (pp. 46-47, apud ACQUiER, "Los tratados en prosa”, p. 95). Una vez más, el único modo de medrar en la corte es simulando y engañando. 
Cortesano (devaneen como quisieren los de vuestra parcialidad), sólo la vida privada se ha de buscar, que la pública sólo es buena para ser apuntado con el dedo, i esto basta para no poder uno usar de su libertad" (p. 70). Por eso:

Como se tenga lo preciso i suficiente para poder passar, el no ser visto ni oído viene a ser la mayor comodidad. Échense enhorabuena a cuestas los validos las penalidades del govierno, que cuanto de más alta jerarchía fueren tanto los tendré por más desatinados, i por más venturosos a los que ni de vista los conocieren. Harto hará el más retirado en saber governarse a sí mismo. Muchos quedan para essotro. Ni yo quiero ser uno d'ellos, ni voy en esta singularidad contra el bien común (pp. 70-71).

Y no sólo hay que pasar inadvertido, sino también reducir las intervenciones públicas a aquellas en las que se pueda modificar algo; esto es, se debe vivir conformándose con la tolerancia de lo que no puede ser cambiado. Así, como parte de aquello a lo que es necesario resignarse, hace en el texto una de sus breves apariciones la figura del valido: "Forçoso es el haver ministros que nos goviernen; forçoso también que éstos tengan criados i confidentes, i muy comunes, si no inexcusables, en la naturaleza humana los yerros i los engaños en los unos i los otros" (p. 73). Esta alusión muestra hasta qué punto la figura del valido o del favorito está atenuada en las Paradoxas, tan presente en cambio en los dos tratados anteriores ${ }^{58}$. Pero debe considerarse que, por un lado, tanto El perfeto señor como Heráclito i Demócrito son textos escritos bajo el directo amparo de la aristocracia y, en segundo lugar, que esta atenuación en buena medida puede obedecer al definitivo triunfo de la facción aristocrática sobre el CondeDuque de Olivares en $1643^{59}$.

La recomendación de tolerar lo inexcusable vuelve a aparecer, ahora en relación con la "profesión de las armas", cuando el Filósofo discurre sobre la existencia de guerras, ejércitos y escuelas militares:

${ }^{58}$ Así por ejemplo, en el sueño político, el autor instruía sobre los privados: "En las de los Privados es aun necessario mayor recato: ...l quien pudo hazer suya la voluntad del absoluto, podrá ta[m]bién representarle por libertad contra ella todas las que fueren contra su fortuna" y "Sea la amistad con tal destreza, que ni se descubran los intentos de grangería, ni se estreche la familiaridad a mas de lo que parezca buena correspondencia" (El perfeto señor, pp. 28 y 31, apud AcQuier, "Los tratados en prosa", pp. 96-97).

${ }^{59}$ Véase F. Benigno, op. cit., pp. 197 ss. 
no es para mí lo inescusable razón para la aprobación, sino para la tolerancia. Sé quan desordenado está el mundo, sé que más vezes se gobierna con la violencia que con la suavidad, i sé que siendo assí viene a ser conveniente el aprenderse por arte la misma violencia. A este blanco mira, o deve mirar, quanto los escritores i quanto las Repúblicas dizen i disponer sobre el arte militar (p. 77-78).

El tema de la guerra ocupa la mayor parte de la "Paradoxa cuarta". El filósofo define las guerras como "odios i enemistades públicas de multitud de hombres contra hombres, executadas, permitidas i aun premiadas por gobierno público" (p. 82) y analiza, antes que nada, sus causas:

Sus causas i motivos son: algunas vezes la común defensa del Reyno, de la Provincia o de la Patria; pocas la de la Religión; pero muchas sólo la ofensa de los estraños... i está emprendida i governada casi siempre por los temas, puntillos de razón de Estado, venganças o conveniencias imaginarias de los Príncipes ( $i d$.).

Más adelante, en una página con varias correcciones marginales que tienden a modalizar las afirmaciones, el filósofo vuelve a referirse a la cuestión de las guerras por motivos religiosos:

La defensa del reino, de la provincia o de la patria, dixe que era algunas vezes el motivo, i muy raras oy (desnudo de otros intentos, se entiende) la de la Religión... En la defensa de la ley, el zelo santo de volver i dar la vida por ella, i esto quando sea necessario, es indubitable ser de mayor importancia que la defensa i conservación de la misma vida. Pero ya los tiempos d'esta necesidad passaron, que ningún infiel nos acomete por causa sólo de la religión; que aunque el odio que nos tienen sea por esso, respetos temporales son los que los mueven a infestar nuestras fronteras (que es sólo donde oy nos inquietan de propósito, aunque tal vez acaso donde quiera que nos encuentren), no el solicitar que seamos infieles como ellos i dilatar assí su seta. İ assí, ya esta guerra defensiva a que nos provocan no se dirá con propiedad que es defensa de la ley, sino del reyno o de la patria, bien que no se puede negar que por ser los contrarios infieles va en cada soldado de los nuestros más justificado, o por lo menos no tan reprehensible, el odio. No es así en las que se hazen contra cathólicos, aunque por cualquiera respeto público sean defensivas (pp. 84-85).

Así, no es difícil llegar a una idea del rey totalmente secularizada; un príncipe temporal con recursos propagandísticos para legitimar sus "razones de Estado": 
Qué diremos luego de los que con tanto denuedo i coraje se hazen parte interesada en las guerras ofensivas tomando en sí los enojos de sus príncipes, i las más vezes los caprichos, temas i desatinos de su mala o buena razón de Estado? "Por la ley, por la grey i por el rey" suelen traer por adagio que es lícita i loable la guerra; pero ésta i semejantes sentencias que introduxo la política tienen para con los píos i sabios tantas inteligencias i limitaciones, que es también simpleza el governarse por ellas a ojos cerrados (p. 85).

El filósofo sigue refiriéndose inmediatamente a los reyes. Se pone de manifiesto la conciencia de los recursos de la monarquía para construir consenso, de aquello que Maravall ha llamado una "cultura dirigida":

I en esto digo que la soberanía en que ya el poder, ya la adulación, tienen puesto a los reyes i se arrogan también algunas repúblicas libres, no contentándose con sujetar los cuerpos de los súbditos, se ha estendido a querer subordinar también los entendimientos i a persuadirnos que no sólo los devemos obedecer i servir con los miembros, más aún con la razón, dando a todas sus determinaciones el mismo crédito que a las divinas, i con repugnancia muchas vezes d'éstas i de la ley natural en que se fundan (p. 86).

La indeterminación de "algunas repúblicas libres" pierde toda ambigüedad posible en tanto el filósofo se incluye en la primera persona del plural: "persuadirnos", "debemos obedecer". El pasaje es, claramente, la queja de un particular sobre el gobierno de la república. No es casual que, al amparo de esta visión de lo político y lo social, el filósofo a menudo eche mano del concepto de bien común; puesto que el "bien común" constituye el límite jurídico más importante para el absolutismo.

Charles Quint, puis Philippe II, mettent davantage l'accent sur la sacralization du pouvoir lorqu'iis imposente la figure du roi comme personne sacrée, représentant de Dieu sur la terre. Le culte bourguignon du prince contribue à établir le concept de souveraineté de droit divin. La practique politique entre en contradiction avec les théories du pouvoir alors en vigueur et enseignées dans les universités espagnoles par les maîtres de la scolastique attachés à la garantie contractuelle du bien commun. López de Vega entérine cette orientation césariste du pouvoir, mais en conserve la finalité héritée de la pensée thomiste: celle du bien commun ${ }^{60}$.

${ }^{60}$ ACQuier, "El perfecto señor...", p. 634. El historiador Tulio HalPerín 


\section{LA "ESPERANÇA DE PODER HALLAR EN ESTE PAPEL OPINIONES SEMEJANTES"}

Como se ha visto hasta aquí, es posible rastrear en el texto una serie de discusiones políticas. Ahora bien, ¿đdesde qué posición se interviene en esas discusiones? Puesto que no se trata de un arbitrista, ni de un tratadista relacionado con la administración, ¿cuál es la legitimidad que el filósofo reclama para sí a la hora de hablar de política? La primera paradoxa parece ofrecer la respuesta, "escrita en forma de diálogo del género activo". Sobre este texto el autor da en el prólogo un dato curioso:

El Discurso del Solitario en la corte... no va por ello con mucha desproporción en compañía de los cinco, como ni tampoco por el sentimiento paradóxico, en que también conviene con ellos. Hízose mucho antes, aunque en estilo más escrupuloso, i se dexó,

DONGH1, en su libro Tradición política española e ideología revolucionaria de Mayo (CEAL, Buenos Aires, 1985), ha trabajado con detenimiento la importancia teórico-política de la noción de bien común, que aparece en autores como Francisco de Vitoria -en su "De potestate civili", en Reverendi Patris F. Francisci de Vitoria Relectiones Theologices, Jacobum Boyerium, Lugduni, 1607, t. 12- o Francisco Suárez -en su Tractatus de legibus et legislatore Deo, impreso en $R$. P. Francisci Suarez Opera omnia, Paris, 1856. La noción conlleva la idea de un doble contrato (pacto societatis y pacto subjectonis) y en el siglo xvu se relaciona íntimamente con la secularización del ámbito de la política: " $\mathrm{La}$ creciente autonomía de lo político -marcada ya por Vitoria, acentuada por Suárez-se advierte aún con mayor claridad en lo que toca a la doctrina del fin del poder, más detalladamente estudiada por Suárez que por Vitoria. Ahora no se trata tan sólo de señalar que el fin del poder político es necesariamente profano, sino que es un fin político. El bien común es ahora definido como la felicitas civitatis y la de los ciudadanos en cuanto tales. El mismo Suárez se encarga de señalar hasta qué punto su concepción del bien común es limitativa: se mantiene, por ejemplo, al margen de toda moral privada, aun de la meramente natural... En Suárez el bien común es ante todo el bien subjetivo de la comunidad política... Si este bien común es todavía el fin según el cual debe orientar su acción el poder político, sería absurdo esperar que a través de esa orientación el poder venga a hallarse vinculado por consideraciones no estrictamente profanas y políticas: por el contrario, al seguirla viene a confirmarse Suárez en su tendencia a ver en la política una actividad profana, dotada de una legalidad que le es propia" (op. cit., p. 36). Más allá de estos vaivenes teóricos y prácticos que sufre (su atenuación, por ejemplo, durante el Barroco debido a las necesidades del antiguo régimen), vuelve a aparecer en toda su dimensión política-ambiguamente entremezclado con nociones propias del iluminismo- en las argumentaciones contractualistas que se esgrimen en América ante la caída de Fernando VII. 
por esso, de imprimir entonces. Va agora menos ofensivo, si no del todo inocente (p. 8).

Desde las primeras páginas, el manuscrito tiene en sí el problema de los límites de lo que puede ser dicho y en alguna medida, por lo tanto, de la censura. Enrique Gacto, que ha ensayado un acercamiento a la "incidencia social del control ideológico ejercido en España por el Santo Oficio" en la literatura de creación del siglo XVII, dice que

como rasgo sobresaliente de la censura inquisitorial, podríamos destacar el de su arbitrariedad, entendida como ausencia de criterios objetivos y firmes que pudieran servir de referencia al escritor para evitar sus efectos. Esta característica, beneficiosa sin duda para los fines perseguidos por la Inquisición, debió resultar, en cambio, abrumadora para los afectados. Benefició a la filosofía latente en la censura, porque, ante el temor a incurrir en dificultades, el autor de un libro se pensaría más de una vez cada palabra, cada frase, cada escena o cada situación que, en la forma o en el fondo, pudiera ser interpretada como materia censurable. Y, por lo mismo, hubo de volverse odiosa para el escritor, que se convierte así en censor de sí mismo, angustiado por las interpretaciones a que sus palabras pudieran dar lugar... Entra en acción de este modo la autocensura, lo que Márquez ha llamado censura inmanente, esa represión interna que surge como consecuencia de saber que existe un riesgo y una responsabilidad, por lo que uno escribe, aunque en el momento oportuno se hubiera conseguido el correspondiente permiso administrativo para publicar ${ }^{61}$.

De allí, sin duda, la cantidad de correcciones que muestra el manuscrito, que incluso llegan a consistir en la adición de hojas sueltas cuyo contenido es sin duda problemático (probablemente agregadas después de la aprobación). De allí también, quizás,

61 "Inquisición y censura en el Barroco", en Francisco Tomás y Valiente et al., op. cit., pp. 156-157. GACTO agrega que "En este sentido cobran un interés mayúsculo los manuscritos originales (para hablar de dos figuras soberanas de nuestras letras), los manuscritos de Quevedo o de Cervantes, porque nos permiten sorprenderles en medio de una nerviosa actividad, y casi podemos verlos corrigiendo, tachando, ensayando variaciones distintas sobre un mismo tema, expresiones diferentes para ver lo mismo con otras palabras, en un intento de poner a salvo sus escritos $o$, al menos, de hacerlos menos vulnerables ante la amenaza inquisitorial" (art. cit., p. 157), fenómeno que, sin duda, puede verse en el libro de López de Vega. 
la revisión de la primera de las "paradoxas" para hacerla "menos ofensiva" 62 .

Más allá de los posibles problemas con la censura (o, si se prefiere evitar el Santo Oficio como motivo de las precauciones y preocupaciones del escritor, pueden considerarse los problemas relativos al "límite de lo que puede ser dicho" según el estricto código de los ámbitos literario y político de la época), la importancia de la paradoxa "El solitario en la corte" radica en que, al ser un diálogo referido por un narrador, ofrece un marco que presenta y ubica a los personajes. El narrador describe la situación en la que conoce al filósofo de esta primera sección. El texto comienza anticipando la extrañeza de este hombre, extrañeza tal que ni siquiera una sentencia de Aristóteles puede dar cuenta de él:

Homo solitarius, aut Deus aut bestia, dixo Aristóteles. Pero ni bestia ni Dios me he topado yo: un solitario en medio del siglo, señores

62 Sin embargo, tampoco parece prudente exagerar la incidencia de la censura. Sin duda el texto ofrece pasajes conflictivos, pero debe recordarse que, como señala GaCTo, a pesar de esta inconsecuencia y arbitrariedad de la censura, puede reconocerse la existencia de ciertas constantes de funcionamiento, una de las cuales es la discrecionalidad con que se trataban los textos de acuerdo con "la amistad, la enemistad, la simpatía o la antipatía entre los calificadores de turno y el escritor" (art. cit., p. 159). Ya fue mencionada la posible relación amistosa de López de Vega con uno de los censores, el padre Agustín de Castro, jesuita y "Predicador de Su Magestad" (p. 2). Su aprobación dice que "no podía ser paradoja la aprobación de obra de tal autor... que no sólo no offende la fe y relligión sino que tiene uerdades que se parecen a ella. ¿Qué paradoja más desconocida para la gentilidad que la unidad de Dios contra su errada muchedumbre? ¿Qué paradoja más diffícil para el juc aísmo, que conocía un Dios, que conocerle trino en personas, al que confessaba uno en la essencia? ¿Qué paradoja mayor para el mundo estragado que cualquiera virtud, pues tan desconocidas están todas en el mundo y tanto se estraña la uirtud?... A éstas se parecen las Paradojas de Antonio López de Vega, porque como se ajnstan a la relligión y apoyan la uirtud, parecerán novedades, pero se harán más agradables al gusto quanto más traxeren de nouedad" (p. 2). En la primera aprobación, de fray Juan de Souza, también se habla de la coherencia con la religión de las Paradoxas racionales: "todo lo que en ellas se resuelve me parece tan conforme a la buena razón, que es necessario considerar quán ageno della está el mundo, para confessar que les viene bien el nombre de Paradoxas, porque no parece possible hallarse algún racional que sienta o haya sentido nunca lo contrario, siendo tan contra lo común todas sus resoluciones. Bien se infiere de aquí que en ningtuna dellas se halla el menor escrúpulo contra la verdad de la Religión i rectitud de las costumbres, antes muchas sentencias i documentos en su favor, que no es la menor singularidad en libro de singularidades" (p. 1). 
entendidos. Su excepción padecen aun los aforismos de los más frunzidos filósofos (p. 10).

Es un amigo, a quien encuentra mientras pasea su "ociosidad... por los barrios de San Bárbara", el que le propone ir a visitar a este "conocido [suyo] retirado", que "es antiguo cortesano, aunque de origen extranjero" (p. 10). La presencia de la ciudad se puede reconocer en el texto y evoca un rasgo propio de la cultura del Barroco; estamos ante lo que Maravall ha llamado una "cultura urbana" 63 .

como a un océano de la urbanidad i del saber vienen a parar a Madrid, no sólo los ríos de la literatura i cortesanía de Hespaña, mas también muchos de las naciones extrangeras, aunque déstas raras vezes viene por acá lo eminente, o sea por mejor acomodados en sus patrias, donde las letras tienen más estimación, o porque la diversidad de religión i desaliança de los reynos no se lo permite (p. 18).

Pero el retiro de este filósofo es ambiguo. "Su principal afecto, finalmente, es el amor de la soledad. I el saber hallarla a vista de las perturbaciones de la corte dize que es su mayor deleyte, añadiendo tan buenas razones de no ir a buscarla más lexos, que

${ }^{63} \mathrm{El}$ "retiro" de la corte es también el alejamiento de un determinado ámbito de poder: "Déjà Domínguez Ortiz établissait une classification des villes castillanes à partir des groupes qui les contrôlaient. Face aus municipalités dont les conseils municipaux étaient totalement aristocratiques, c'est-à-dire sous le contrôle total de la noblesse comme classe dirigeante fermée (Córdoba, Sevilla, Guadalajara, Madrid, Valladolid, p. ex.)" (RAúl Molina Recio, AntonioJ. Mialdea Baena y Juan A. Gavilán Sánchez, "Les manifestationes du pouvoir dans le ville: Cordoue, $\mathrm{xvI}^{\mathrm{e}}$-xvne siècles", La ville en Europe..., p. 16). Dentro de ese marco general en el que la nobleza controla la corte, Madrid es un caso aparte en tanto no puede observarse la primacía de una determinada familia: "Madrid constitue un example un peu different, que nous connaissons grâce au travail de Mauro Fernández. Il montre que le pouvoir municipal se trouve bien partagé dans cette ville. Malgré le fait que l'accès aus charges publiques -qui contrôlent les ressorts de la vie citoyenne-soit restreint à la noblesse, on ne trouve aucun lignage qui accaperera d'une manière notable le contrôle municipal. Bien plus, la plupart des membres de cette noblesse sont d'un rype moven et, souvent, d'une origine roturière de sorte que Madrid est define par l'auteur comme une ville contrôlée par une oligarchie à cheval entre la bourgeoisie et les couches inférieures de la noblesse" (loc. cit.). Los mismos autores recuerdan que una de las estrategias para restringir el acceso al poder en el consejo municipal era la exigencia de prueba de nobleza y de pureza de linaje (ibid., p. 17). 
dexa sin réplica a los pocos a quien se digna de dar cuenta de su vida" (p. 11). El mismo filósofo, cuando ya los dos personajes, el narrador y su amigo, lleguen a su casa y entablen conversación, definirá su situación como "voluntaria soledad en medio de una corte" (p. 13). Es decir que el personaje del filósofo, con el que claramente se identifica el autor, no está ni en el campo ni en la ciudad. Está a mitad de camino, tiene la posibilidad tanto de dirigirse hacia uno como hacia la otra.

El espacio intermedio en el que se desarrolla la reflexión y la discusión libres aparece también en el anterior tratado de López de Vega. En Heráclito i Demócrito el diálogo transcurre en un espacio similar:

La conversación tiene lugar en la morada de Demócrito (el personaje principal con el que el autor practica de ventrílocuo), habitación confortable con vistas a una calle de abundante trajín y dotada además de un huerto interior; y así los amigos, según la hora o su temple, dirigen su atención hacia los ruidos del mundo o la tranquilidad de la domesticada naturaleza, para entreverar observaciones visuales a sus excursiones especulativas ${ }^{64}$.

Si interesa el espacio en el que se desarrollan estos diálogos es porque son mucho más que una excusa argumental. Son la representación del lugar de legitimidad desde el cual hablan los personajes de Demócrito y del filósofo en cada uno de los libros. En el final de la primera paradoxa el narrador explicita las intenciones de publicar el diálogo que tuvo con el filósofo:

Hálleme después en mi casa, no sólo consolado por haver topado sentimiento tan parecido al mío, mas aun animoso para no recatar el publicarle en esta forma, assí porque aquel exemplo me puso en esperança de poder hallar este papel opiniones semejantes $\mathbf{i}$ no quedar de mi sentimiento odioso, por singular, como porque la circunspección de la generalidad con que va escrito aun en los mismos delinquentes me puedo prometer que halle más crédito de fraternal advertencia que de razón de escándalo (p. 33).

Se trata entonces de construir un consenso de particulares. Se trata también del diálogo privado y libre sobre las materias del Estado y del gobierno. Se trata, en suma, de la opinión pú-

64 Garagorr1, art. cit., p. 112. 
blica ${ }^{65}$. Maravall ha señalado la importancia que, mientras se desarrolla la monarquía absoluta, simultáneamente adquiere la opinión. La relación entre opinión y política puede también encontrarse en un contemporáneo de López de Vega; en 1640 Saavedra Fajardo escribe:

El infante don Fernando aconsejaba al rey don Alonso el Sabio, su padre, que antes quisiese ser amado que temido de sus súbditos, y que granjease las voluntades del brazo eclesiástico y del pueblo, para oponerse a la nobleza: consejo que si lo hubiera executado, no se viera despojado de la corona... La grandeza y el poder del rey no está en sí mismo, sino en la voluntad de sus súbditos ${ }^{66}$.

Un modo de pensar la política que, si atiende a la construcción de consenso, atiende igualmente a la necesidad de una "especialización" de un oficio que, cada vez más, se percibe como profano:

Para el trabajo nacieron los príncipes, y conviene que se hagan a él... No consentirán algunos príncipes presentes tan molesto despertador; porque muchos están persuadidos a que en ellos el reposo, las delicias y los vicios son el premio del principado, y en los demás la vergüenza y el oprobio. Casi todos los príncipes que se pierden es porque... se persuaden que el reino es herencia y propiedad... El remedio destos inconvenientes consiste en dos cosas: la primera, en que el príncipe, luego en teniendo uso de razón, se vaya introduciendo en los negocios antes de la muerte del antecesor... La segunda, en que con destreza procuren los que asisten al príncipe quitarle las malas opiniones de su grandeza, y que sepa que el consentimiento común dió respeto a la corona y poder al ceptro; porque la naturaleza no hizo reyes; que la púrpura es símbolo de la sangre que ha de derramar por el pueblo,

65 Me refiero al concepto de öffentlichkeit (literalmente "publicidad") que JÜRGEN HABERMAs ha trabajado en su libro Historia y crítica de la opinión pública. La transformación estructural de la vida pública, Gustavo Gili, Barcelona, 1997.

${ }^{66}$ Diego de SaAvedra Faja Rdo, Idea de un príncipe político-cristiano en cien empresas, en Obras completas, ed. A. González Palencia, Aguilar, Madrid, 1946, empresa XXXVIII, p. 343. MARAVALL cita un ejemplo igualmente contundente: "En el campo de la política vale, en términos generales, la observación de J. A. de Lancina, compatible con el absolutismo: «Ha de procurar un príncipe que sean tales las máximas de su gobierno que tengan el aplauso de los súbditos». En cualquier caso, ha de obrar con los medios aptos para atraerles y sujetarlos, teniéndolos asombrados, suspendidos, atemorizados-medios que pertenecen al terreno de la psicología de masas" (op. cit., p. 204). 
si conviniere, no para fomentar en ella la polilla de los vicios; que el nacer príncipe es fortuito, y solamente propio del hombre la virtud; que la dominación es gobierno, y no poder absoluto, y los vasallos, súbditos, y no esclavos ${ }^{67}$.

En cuanto a las Paradoxas racionales, el título mismo del libro muestra esa suerte de "oxímoron cultural" en el que se encuentra. Por un lado en la idea de paradojas puede leerse el gusto barroco por el juego conceptuoso de oposiciones y por el claroscuro; a la vez, estas paradojas son racionales, y la idea de racionalidad ya remite al siglo xvir. Pero, como se ha visto, la racionalidad que López de Vega reclama es la racionalidad pragmática de la vida retirada y tranquila, no la del conocimiento por el conocimiento ${ }^{68}$. Nos encontramos, por tanto, lejos aún de la idea iluminista de la razón como capacidad humana prácticamente todopoderosa.

Aquí, por encima de la razón destaca un pragmatismo exacerbado, que puede verse en la ambigua relación que entabla con la ciudad. El filósofo rechaza el campo como lugar habitable. Tampoco acepta indiscriminadamente la vida en la corte. Prefiere un ámbito intermedio, bifronte como Jano, aquel propio de la distinción de las esferas de lo privado y lo público. Esa solución intermedia habla de la fuerza que se percibía en la política del antiguo régimen. El filósofo, una suerte de ermitaño sociable, se contenta con mantenerse no ya lejos, sino al lado del mundanal ruido.

Las Paradoxas racionales prueban como pocos textos que a mediados del siglo xvn, en el ocaso del Barroco, el pensamiento

67 SaAVEdra Fajardo, op. cit., empresa XX, pp. 259-260. La importancia otorgada a la opinión de los súbditos, como se ve, se relaciona con el señalamiento de la insuficiencia de la nobleza de sangre. Este punto en común con López de Vega puede observase en distintos pasajes del libro de Saavedra Fajardo: "Un acto solo derriba la reputación, y muchos no la pueden restaurar; porque no hay mancha que se limpie sin dejar señales, ni opinión que se borre enteramente... No es bastante la sangre real ni la grandeza de los estados a mantener la reputación, si falta virtud y valor propio, como no hacen estimado al espejo los adornos exteriores, sino su calidad intrínseca: en la maiestad real no hay más fuerza que el respeto, el cual nace de la admiración y del temor, y de ambos la obediencia" (ibid., empresa XXXI, pp. 312-313).

68 "What emerges from such a sceptical account of human knowledge is a picture of the wise man as a realist, choosing activities and limiting his objectives according to the dictates of intellectual pragmatism" (RoBBins, art. cit., pp. 141). 
español estaba dispuesto a recibir las ideas racionalistas que desembocarían en el iluminismo del Siglo de las Luces. Es decir, dejan constancia de una tendencia que acallarian otras fuerzas, también desarrolladas por el Barroco, justamente aquellas que López de Vega denuncia. Resulta entendible que su texto haya permanecido durante tres siglos, en el literal y en el metafórico sentido de la palabra, inédito.

En resumen, la modernidad de las Paradoxas racionales, pues, no radica tanto en la reivindicación de la razón (que como vimos es una razón despojada de los atributos "omnipotentes" que adquirirá en el iluminismo) sino en la figuración de una individualidad libre, en la apología de una privacidad en que ningún poder temporal puede incidir ni determinar fundamentos. Esa individualidad privada es la condición de posibilidad del individuo moderno. No es que la distinción entre vida privada y vida pública no existiese (allí están los tomos de la Historia de la vida privada que dirigieron Philippe Ariés y Georges Duby para demostrarlo), sino que esa escisión no se conceptualizaba como tal ni era percibida como el cimiento de la libertad de opinión:

Por espacio público entendemos un ámbito de nuestra vida social, en el que se puede construir algo así como opinión pública. La entrada está fundamentalmente abierta a todos los ciudadanos. En cada conversación en la que los individuos privados se reúnen como público se constituye una porción de espacio público... Los ciudadanos se comportan como público cuando se reúnen y conciertan libremente, sin presiones y con la garantía de poder manifestar y publicar libremente su opinión, sobre las oportunidades de actuar según intereses generales ${ }^{69}$.

No es casual que en la paradoxa cuarta, acaso la que contiene más referencias a la política, aparezca por primera vez el tema de la privacidad del conocimiento que dialogan el cortesano y el filósofo. El cortesano cuenta al filósofo que en "cierta conversación de palaciegos" cometió la imprudencia de contestar a un cortesano argumentando según lo aprendido en los diálogos con el filósofo; la incomprensión con que fueron recibidas sus palabras le hace concluir: "i yo saqué por fruto del encuentro un

69 Jürgen Habermas, "Offentlichkeit (ein Lexikonartikel) 1964", reed. en Kultur und Kritik, Suhrkamp, Frankfurt/M., 1973, p. 61, apud MARGARITA Bo1 aderas Cucurella, "La opinión pública en Habermas", Anàlisi, 26 (2001), $51-70$. 
propósito firme de no reincidir en el riesgo de referir vuestras Paradoxas delante de gente lega, por más cortesana que sea" (p. 76); propósito que el filósofo aprueba: "yo también no las digo a todos" (p. 77). No deja de ser llamativo que la pretensión de seleccionar el auditorio aparezca en un texto que se preparó para ser publicado como impreso, es decir reproducido mecánica y masivamente.

En la corte barroca, entonces, no se tratará solamente de pasar inadvertido, también habrá que ocultar lo que se piensa: "Donde essa gente [los que apoyan el arte militar y, en general, los «irracionales»] pueda oírlo, ni en essa materia ni en otra que pida oyentes racionales hablaré yo nunca palabra" (p. 82). Sin duda el filósofo no se equivoca. Sus Paradoxas racionales dejan testimonio de una modernidad que no estaba lista sino para permanecer inédita. Nuevamente en este aspecto el libro, de una ambigüedad fascinante, conjuga dos épocas: porta en su escritura el sorprendente anticipo de la modernidad en ciernes; queda, en el hecho de haber permanecido encerrado en el silencio solitario del manuscrito inédito, el mayor testimonio de su singularidad en la cultura del Barroco.

César A. Núñez

El Colegio de México 
